\title{
Can we reconcile differences in estimates of carbon fluxes from land-use change and forestry for the 1990s?
}

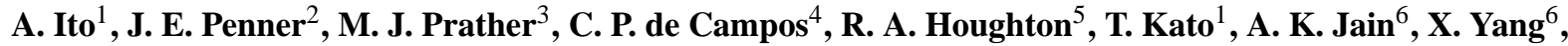 \\ G. C. Hurtt ${ }^{7}$, S. Frolking ${ }^{7}$, M. G. Fearon ${ }^{7}$, L. P. Chini ${ }^{7}$, A. Wang ${ }^{8}$, and D. T. Price ${ }^{9}$ \\ ${ }^{1}$ Frontier Research Center for Global Change, JAMSTEC, Yokohama, Japan \\ ${ }^{2}$ Department of Atmospheric, Oceanic and Space Sciences, University of Michigan, Ann Arbor, Michigan, USA \\ ${ }^{3}$ Earth System Science Department, University of California at Irvine, Irvine, California, USA \\ ${ }^{4}$ Petrobras Research \& Development Center, Rio de Janeiro, Brazil \\ ${ }^{5}$ The Woods Hole Research Center, Woods Hole, Massachusetts, USA \\ ${ }^{6}$ Department of Atmospheric Science, University of Illinois, Urbana, Illinois, USA \\ ${ }^{7}$ Institute for the Study of Earth, Oceans, and Space, University of New Hampshire, Durham, New Hampshire, USA \\ ${ }^{8}$ Department of Renewable Resources, University of Alberta, Edmonton, Alberta, Canada \\ ${ }^{9}$ Natural Resources Canada, Northern Forestry Centre, Edmonton, Alberta, Canada
}

Received: 13 November 2007 - Published in Atmos. Chem. Phys. Discuss.: 25 February 2008

Revised: 16 May 2008 - Accepted: 3 June 2008 - Published: 27 June 2008

\begin{abstract}
The effect of Land Use Change and Forestry (LUCF) on terrestrial carbon fluxes can be regarded as a carbon credit or debit under the UNFCCC, but scientific uncertainty in the estimates for LUCF remains large. Here, we assess the LUCF estimates by examining a variety of models of different types with different land cover change maps in the 1990s. Annual carbon pools and their changes are separated into different components for separate geographical regions, while annual land cover change areas and carbon fluxes are disaggregated into different LUCF activities and the biospheric response due to $\mathrm{CO}_{2}$ fertilization and climate change. We developed a consolidated estimate of the terrestrial carbon fluxes that combines book-keeping models with process-based biogeochemical models and inventory estimates and yields an estimate of the global terrestrial carbon flux that is within the uncertainty range developed in the IPCC 4th Assessment Report. We examined the USA and Brazil as case studies in order to assess the cause of differences from the UNFCCC reported carbon fluxes. Major differences in the litter and soil organic matter components are found for the USA. Differences in Brazil result from assumptions about the LUC for agricultural purposes. The effects of $\mathrm{CO}_{2}$ fertilization and climate change also vary significantly in Brazil. Our consolidated estimate shows that the small
\end{abstract}

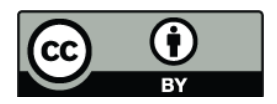

Correspondence to: A. Ito (akinorii@jamstec.go.jp) sink in Latin America is within the uncertainty range from inverse models, but that the sink in the USA is significantly smaller than the inverse models estimates. Because there are different sources of errors at the country level, there is no easy reconciliation of different estimates of carbon fluxes at the global level. Clearly, further work is required to develop data sets for historical land cover change areas and models of biogeochemical changes for an accurate representation of carbon uptake or emissions due to LUC.

\section{Introduction}

Changes in the carbon pools for the terrestrial biosphere result in the uptake or release of carbon dioxide $\left(\mathrm{CO}_{2}\right)$ from the atmosphere and thus shape climate change for the next century. During the 1990s fossil-fuel and industrial emissions averaged $+6.4 \pm 0.4 \mathrm{PgC} \mathrm{yr}^{-1}$, the oceanic flux was $-2.2 \pm 0.4 \mathrm{PgC} \mathrm{yr}^{-1}$ (uptake), and the terrestrial flux was $-1.0 \pm 0.6 \mathrm{PgC} \mathrm{yr}^{-1}$ (uptake) (AR4; Denman et al., 2007). The terrestrial flux can be split into that part specifically attributable to Land Use, Land Use Change and Forestry (LULUCF) and a residual component that accounts for other environmental changes (ENV). These LULUCF fluxes are mainly attributable to human activities and are reported for managed lands under the United Nations Framework Convention on Climate Change (UNFCCC) reporting guidelines,

Published by Copernicus Publications on behalf of the European Geosciences Union. 
although LULUCF inevitably contains a component due to ENV changes (for this reason sinks from forest management were reduced by $85 \%$ and capped under the Kyoto protocol). Managed land is used in the IPCC guidelines for land where human interventions and practices have been applied to perform production, ecological or social functions (IPCC, 2003, 2006). Over the past two decades, tropical deforestation has been the dominant component of the global LUCF $\mathrm{CO}_{2}$ flux, which excludes the $\mathrm{CO}_{2}$ fluxes from agricultural practices (Denman et al., 2007). Since the global $\mathrm{CO}_{2}$ flux from agricultural land use practices is much smaller than that from LUCF (UNFCCC, 2005, 2007), tropical deforestation is also the dominant component of LULUCF. The residual terrestrial flux can be associated with a wide range of environmental changes which include climate change (water and temperature), disease outbreaks, added nutrients $\left(\mathrm{CO}_{2}\right.$ and nitrates), pollution damage $\left(\mathrm{O}_{3}\right)$, and re-growth of vegetation in natural (unmanaged) land that is not included under the UNFCCC reporting guidelines for LULUCF. Interpretation of the guidelines needs cautions. For instance, the Intergovernmental Panel on Climate Change (IPCC) and Food and Agriculture Organization (FAO) definitions and methodologies differ slightly as discussed in the IPCC Special Report on LULUCF (IPCC, 2000). In many cases these ENV fluxes may be indirectly attributed to human activities. As seen from the uncertainties above, it is difficult to separate LUCF and ENV emissions (House et al., 2003), much less to attribute national ENV fluxes.

Quantifying the net emissions from terrestrial sources is particularly important for meeting climate stabilization goals, since individual countries can be given carbon credit or debits for LULUCF uptake and emissions for "managed lands" under the UNFCCC. These countries compile national greenhouse gas inventory data (e.g., Brazil Ministry of Science and Technology, 2004; US Environmental Protection Agency, 2007) which are reported to the UNFCCC and archived in the UNFCCC database (UNFCCC, 2005, 2007). Net Global Warming Potential (GWP) weighted $\mathrm{CO}_{2}$ fluxes of $\mathrm{CO}_{2}, \mathrm{CH}_{4}$ and $\mathrm{N}_{2} \mathrm{O}$ for LULUCF in the 1990s as reported to the UNFCCC were $-0.22 \mathrm{PgC} \mathrm{yr}^{-1}$ and $-0.08 \mathrm{Pg} \mathrm{C} \mathrm{yr}^{-1}$ for the USA and the 15 Annex I European countries, respectively (UNFCCC, 2007). This uptake offsets roughly $12 \%$ and $7 \%$ of these countries' emissions from fossil fuel use and cement manufacture, respectively. Scientific uncertainty in such LULUCF emissions remains large (Prather et al., $2008^{1}$ ).

The reported flux of only $\mathrm{CO}_{2}$ from LULUCF for the Annex I less Russia (Annex I-R) countries from the UNFCCC database is of order $-0.35 \mathrm{PgC} \mathrm{yr}^{-1}$ while estimates based on three LUC data bases for cropland conversion (Ramankutty and Foley, 1998, 1999; Klein Goldewijk, 2001;

\footnotetext{
${ }^{1}$ Prather, M., Penner, J. E., Fuglestvedt, J. S., et al.: From human activities to climate change: Uncertainties in the causal chain, in preparation, 2008.
}

Houghton, 2003) together with a carbon-cycle model using observed temperatures and $\mathrm{CO}_{2}$ concentrations (Jain and Yang, 2005) had fluxes from LUC varying between -0.1 and $+0.1 \mathrm{PgC} \mathrm{yr}^{-1}$ during this period (Prather et al., 2008). The differences between the UNFCCC-reported fluxes and those of the carbon cycle model are significantly larger than the uncertainty range determined by a sensitivity study that varied the carbon-cycle parameters that control the amount of ocean and land uptake (Prather et al., 2008). The key question here is whether the official reporting and the carbon cycle models are including the same terrestrial components and LULUCF activities with the same definitions. The UNFCCC-reporting meets a political need for responsibility of reporting, but verification of these $\mathrm{CO}_{2}$ fluxes is not yet available (e.g. US Environmental Protection Agency, 2007). Thus, it is important to determine the causes of such differences.

Carbon cycle models show a wide range in net $\mathrm{CO}_{2}$ emissions associated with LUC activities due to the inclusion of different processes (McGuire et al., 2001). The range encompasses the result from the carbon-cycle model developed by Jain and Yang (2005) using the same land cover change data set (Ramankutty and Foley, 1998, 1999). Differences in the magnitudes of the modeled LUC fluxes are increased when different historical land cover databases (Houghton and Hackler, 1999; Houghton, 2003) are used (Jain and Yang, 2005). Especially, large model differences exist in the tropics, where there are no reliable observations of gross LUC areas (House et al., 2003). The methods used to estimate the terrestrial carbon fluxes include inverse models, bottom-up inventories and carbon cycle models. Inverse models directly solve for the net flux of $\mathrm{CO}_{2}$ from large continental-scale regions, have large uncertainties, and are not able to associate the net fluxes with particular processes. Recent results from inversion models indicate a weak net Northern Hemisphere uptake $\left(-1.5 \mathrm{PgC} \mathrm{yr}^{-1}\right)$ and smaller net emissions in the tropics $\left(0.1 \mathrm{PgC} \mathrm{yr}^{-1}\right)$ for $1992-1996$ (Stephens et al., 2007). Bottom-up inventories, such as those used by the UNFCCC, do not always include all processes. Some carbon cycle models, i.e. the so called book-keeping approach, only account for some types of LUCF (e.g. Houghton, 2003; de Campos et al., 2005) while others account for ocean uptake and possible environmental effects (e.g. climate change and $\mathrm{CO}_{2}$ concentration increase), as well as LUC (e.g. McGuire et al., 2001; House et al., 2003; Friedlingstein et al., 2006). The differences in carbon fluxes between top-down inversion estimates and bottom-up model studies are consistent with estimates due to environmental changes from processbased carbon cycle models, but the latter have been criticized since they do not account for residual terrestrial sinks due to agricultural land management, and export of wood products, nor do they account for transport of carbon from land areas to ocean via rivers (House et al., 2003). In general, the mean response of forest net primary productivity to elevated $\mathrm{CO}_{2}$ from six dynamic global vegetation models based on a standard photosynthesis model (Cramer et al., 2001) 
is in good agreement with that from measurements at forest sites (Norby et al., 2005), although comparisons of predicted aboveground carbon uptake with regional-scale forest inventory measurements imply that conventional biogeochemical formulations of plant growth (Farquhar et al., 1980) overestimate the response of plants to rising $\mathrm{CO}_{2}$ levels in forests (Albani et al., 2006).

Houghton and Ramakrishna (1999) have reviewed some of the first emissions inventories from non-Annex I counties and showed that there were significant discrepancies between the data used in the emissions inventories and the data available in international surveys. The disparity of results between the estimated emissions reported to the UNFCCC and modeling approaches such as the carbon cycle models used by McGuire et al. (2001) may be caused by the definition of "managed lands" used by the UNFCCC, by differences in the estimated carbon pools, carbon pool changes, or areas involved in LUC, or even by processes such as $\mathrm{CO}_{2}$ fertilization which are as yet poorly quantified. Here, we seek to understand the difference in net carbon emissions from different land cover change data sets and from different methods of calculating such changes.

This paper focuses on LUCF emissions and evaluates a wide range of models and data sets, ranging from the UNFCCC national reporting via the National Greenhouse Gas Inventory Program (NGGIP), to research-level tools. We particularly aim to reconcile the differences with estimates used by the UNFCCC. First we examine differences in estimates at the global scale. Since individual countries are allowed to use different methods to estimate the carbon flux from LULUCF based on the IPCC guidelines, a careful reading of the national reports and auxiliary materials is required to interpret the estimates for carbon pools, carbon pool changes, and land cover change areas from individual countries in the UNFCCC data base. Here, we focus on two countries as case studies. The USA is chosen because of the large LUC in the past and the disparity between the detailed inventory-based estimates (Woodbury et al., 2007) and the model-based estimates (Houghton et al., 1999; Hurtt et al., 2002; Houghton, 2003). In addition, Brazil is chosen because of recent estimates of large area changes in land use and because of the ongoing negotiations on a mechanism of positive incentives for Reducing Emissions from Deforestation and Degradation (REDD) initiated at the request of several forest-rich developing countries (Gullison et al., 2007; Oliveira et al., 2007). We concentrate our efforts on the period since 1990 when the UNFCCC data sets began. We note that the year 1990 is used as a reference year for the Kyoto protocol including the Clean Development Mechanism (Schulze et al., 2003). In the following, section 2 briefly describes the different land cover change and carbon flux data sets. Sections 3.1-3.3 show comparisons between different data sets at the global or near-global level, while Sect. 3.4 presents the two case studies for the USA and Brazil. Specific issues that we will address for a quantitative interpretation of the USA data in terms of differences in LUCF emissions include (1) the soil organic carbon (SOC) pools, (2) the effects of including fire suppression, and (3) the discrepancies in the amount of sinks between bottom-up and top-down estimates. Specific issues that we will focus on for the Brazilian data with regard to differences in LUCF emissions include (1) the land-use changes areas, (2) the origin and fate of carbon released into the atmosphere, and (3) the discrepancies in the inter-annual variability between bottom-up and top-down estimates. Section 4 presents a summary of our findings.

\section{Materials and methods}

In order to compare available estimates of carbon fluxes from LUCF, we gathered disaggregated data from different LUCF activities and carbon pools. These data are analyzed and compared in Sect. 3. Here, we describe the data sets used in this study. We examine six different data sets of LUC areas (LUC; Table 1) and seven estimates of carbon fluxes (EMI; Table 2). Each data set provides estimates for the 1990s. Consolidated carbon fluxes are constructed from six of the modeled estimates (EMI1, 3, 4, 5, 6, and 7) for the USA and five are used to make a consolidated estimate for Latin America. We also constructed a consolidated estimate of global terrestrial carbon fluxes.

\subsection{Land cover change area}

Afforestation and reforestation (AR) activities refer to the conversion of non-forested land to a forested state according to the IPCC guidelines (2003). Afforestation means the human-induced conversion of lands that previously have not supported forests for more than 50 years at the time of conversion; reforestation refers to the conversion of lands that have supported forests within the last 50 years and where the original forest product has been replaced with a different one (Brown et al., 1986). The use of estimates for the individual gains and losses of carbon from terrestrial ecosystems rather than net land use emission data is important because AR causes a gradual gain in carbon stocks for many decades, while deforestation causes a rapid loss in carbon stocks. Since inventory methodologies for estimating emissions and removal of $\mathrm{CO}_{2}$ from afforestation and reforestation are identical, the two activities can be treated as one for reporting and accounting purposes under the Kyoto Protocol. It is, however, important for modeling the carbon cycle to separate reforestation (continuous cycles of harvest and replanting), because the carbon dynamics are different (e.g. Krankina et al., 2002; Ramankutty et al., 2007). Further, it is crucial to distinguish regions where large area fractions are occupied by regrowing secondary forest from regions dominated by undisturbed mature forest (Houghton et al., 2000; Hurtt et al., 2002), because the accumulation rate of carbon into the terrestrial biosphere varies substantially 
Table 1. Data Sources on Land Cover Change.

\begin{tabular}{llll}
\hline Name & Study & Resolution & Data Source \\
\hline LUC1 & Houghton (2006) & Region/country & FAO (2006) \\
LUC2 & de Campos et al. (2007) & Country & HYDE \& FAOSTAT (2005) \\
LUC3 & Kato et al. (2007) & T42 $\left(2.8^{\circ} \times 2.8^{\circ}\right)$ & SAGE \& HYDE \\
LUC4 & Hurtt et al. (2006) & $1^{\circ} \times 1^{\circ}$ & HYDE \& FAOSTAT (2004) \\
LUC5 & Hurtt et al. (2006) & $1^{\circ} \times 1^{\circ}$ & SAGE \& LUC4 \\
LUC6 & Wang et al. (2006) & $0.5^{\circ} \times 0.5^{\circ}$ & SAGE \& GLC2000 \\
\hline
\end{tabular}

Table 2. Data Sources on Land Use, Land Use Change and Forestry Emissions.

\begin{tabular}{lllll}
\hline Name & Study & Resolution & Method & LUC \\
\hline EMI1 & UNFCCC $(2005,2007)$ & Country & Inventory & National inventory \\
EMI2 & Olivier and Berdowski (2001) & Country & Inventory & FAO \\
EMI3 & Hurtt et al. (2006/2002(USA)) & Country/1 ${ }^{\circ}($ USA) & Inventory/process & National statistics \\
EMI4 & Houghton $(2006)$ & Region/country & Book-keeping & LUC1 \\
EMI5 & de Campos et al. $(2007)$ & Country & Book-keeping & LUC2 \\
EMI6 & Kato et al. $(2007)$ & T42 $\left(2.8^{\circ} \times 2.8^{\circ}\right)$ & Process model & LUC3 \\
EMI7 & Jain and Yang (2005) & $0.5^{\circ} \times 0.5^{\circ}$ & Process model & SAGE \\
EMI8 & This work & Region/country & Consolidated data & N.A. \\
\hline
\end{tabular}

with the age of trees (Brown and Lugo, 1992). In this study, we analyze six different data sets that provide the area associated with different land cover types and their change with time in order to investigate the potential reasons for large differences between different estimates of terrestrial carbon fluxes. These data sets are LUC1 (Houghton, 2006, unpublished), LUC2 (de Campos et al., 2007), LUC3 (Kato et al., $2007^{2}$ ), LUC4 and LUC5 (Hurtt et al., 2006), and LUC6 (Wang et al., 2006).

LUC1 (Houghton, 2006, unpublished) follows the methods reported in Houghton (2003) and used the annual rates of LUC for ten countries or regions comprising the globe. The rates of LUC within each region are based on statistical reports and remote sensing surveys from the FAO. LUC1 uses the FAO (2006) report instead of FAO (2000) which was used by Houghton (2003). The more recent FAO estimate has lower estimates of tropical deforestation for the 1990s.

LUC2 (de Campos et al., 2007) follows methods reported in de Campos et al. (2005) and uses the History Database of the Global Environment (HYDE; Klein Goldewijk, 2001) data set for 1700-1990 and was extended to 2000 by linearly extrapolating the fraction of natural biomes in each country and year using the trend for the period between 1970 and

\footnotetext{
${ }^{2}$ Kato, T., Ito, A., and Kawamiya, M.: Multi-temporal scale variability during the 20th century in global carbon dynamics simulated by a coupled climate-terrestrial carbon cycle model, Clim. Dyn., submitted, 2007.
}

1990. For 1961-2000, LUC2 starts with the fractions of natural biomes derived from HYDE but then adjusts the changes in total natural biomes areas by updating the changes in the agriculture and pasture national rates of change in the FAO Statistical Database (FAOSTAT, 2005).

LUC3 (Kato et al., 2007) uses the reconstruction of cropland developed at the Center for Sustainability and the Global Environment (SAGE; Ramankutty and Foley, 1998, 1999) and pasture land from HYDE for 1900, 1950, 1970 and 1990. For the years in between these, the annual fractional cover of pasture was linearly interpolated in time, and then the pasture and/or crop fractions were modified to ensure that the 2 fractions did not exceed unity (Betts et al., 2007). In LUC3, the SAGE and HYDE data are aggregated onto a model grid of about $2.8^{\circ}$ longitude by $2.8^{\circ}$ latitude (T42) over land areas. Consequently, when natural land is cleared for agricultural purposes while managed land is abandoned within the same aggregated cell, the model treats a net area change that is smaller than the total individual areas experiencing LUC. Thus, total LUC is masked for this data set by the interpolation to a T42 grid. The areas of the natural vegetation lands within the grids are then adjusted to compensate for those vacated or occupied by cropland and pastureland. LUC3 used zero net LUC areas after 1991 on the basis of the assumption that forest areas did not change appreciably in the 1990s (Wang et al., 2006). In our comparison analysis, the LUC3 data set for 1989-1990 was used. 
LUC4 and LUC5 (GLM; Hurtt et al., 2006) provide global gridded estimates of LUC for the period 1700-2000. LUC4 uses the HYDE land-use history data sets for 1700-1990. The fractional pastureland area change for the years between 1990 and 2000 was determined for each country based on FAOSTAT (2004). The data for pastureland in the year 2000 were derived by applying the ratio of pastureland between 2000 and 1990 from FAOSTAT (2004) data to the 1990 values at a 1 degree grid. Annual values were then interpolated linearly between 1990 and 2000. LUC5 also used the HYDE data set but replaced their cropland data with that from the SAGE data products for 1700, 1750, 1800, 1850, $1870,1890,1900,1910,1930,1950,1970$, and 1990, retaining the HYDE data for pasture land but reducing HYDE pasture estimates for grid cells where there was not enough land area to accommodate both SAGE crop estimates and HYDE pasture estimates. Data for years between these was determined by a linear interpolation and data for 1990-2000 by a linear extrapolation based on national statistics (FAOSTAT, 2004) as in LUC4 for pastureland. The original data was aggregated from a 0.5 degree grid to a 1 degree grid.

LUC6 (Wang et al., 2006) combined the annual SAGE data for 1850-1992 with a simple classification from presentday satellite data (GLC2000; Bartholomé and Belward, 2005). LUC6 assumed that changes in the area fractions of all natural plant functional types (PFTs) were inversely proportional to changes in the area fractions of crop PFTs taken from the SAGE data set.

\subsection{Carbon fluxes}

We describe five approaches for determining carbon fluxes: (1) an inventory approach (UNFCCC, 2005, 2007; Olivier and Berdowski, 2001; Hurtt et al., 2006), (2) a book-keeping approach (Houghton, 2006, unpublished; de Campos et al., 2007), (3) a process-based biogeochemical modeling approach (Hurtt et al., 2002; Kato et al., 2007; Jain and Yang, 2005), (4) a consolidated estimate based on (1), (2), and (3) (EMI8) and (5) an inverse modeling approach (Baker et al., 2006). We calculated annual mean carbon fluxes from the biosphere to the atmosphere by averaging net carbon fluxes at the processing time step for each carbon cycle model. We calculated annual carbon stock changes by subtracting carbon stocks in the current year from those in the previous year. According to the IPCC Guidelines (1997), the sign for C sequestration/uptake is always negative (-) and that for emissions positive (+).

\subsubsection{Inventory}

Inventory-based approaches (EMI1, 2, and 3) generally multiply average rates of conversion by representative values of carbon mass in the ecosystems to estimate large scale carbon fluxes. For EMI1, the data are those from the UNFCCC $(2005,2007)$. All Annex I countries and most of the non-Annex I parties report greenhouse gas emissions due to LULUCF and update their estimates according to the IPCC guidelines (2003). The methodology in the IPCC guidelines (1997) for the UNFCCC reporting assumes that net emissions equals carbon stock changes in the existing biomass between two points in time. For EMI1, only the methods used for carbon flux estimates provided in the USA (US Environmental Protection Agency, 2007) and Brazil (Brazil Ministry of Science and Technology, 2004) reports are summarized here.

In the USA, annual estimates of carbon stocks are based on interpolating or extrapolating as necessary to assign a carbon stock to each year. Periodic estimates of carbon stocks are compiled for forest, agricultural lands (i.e. cropland and pastureland) and landfills. In addition, emissions of $\mathrm{CO}_{2}$ due to the application of crushed limestone and dolomite to managed land (i.e. soil liming) are reported. Carbon stocks and fluxes in forests are reported for live aboveground and live belowground biomass (i.e. coarse living roots), dead trees, forest floor litter, and soil organic matter (IPCC, 2003). The forest carbon stocks (except soil organic matter) were derived from an empirical model referred to as FORCARB2 (Birdsey and Heath, 1995, 2001; Heath et al., 2003, Smith et al., 2004a), which provides inventory-based estimates of the carbon stocks from inventory variables (e.g. stand age, forest areas, and volumes), conversion factors and model coefficients. Forest land includes land that is at least 10 percent stocked with trees of any size. Timberland represents most of the forest land in the conterminous USA (79\%; Smith et al., 2004b). The remaining portion of forest land is classified as either reserved forest land, which is forest land withdrawn from timber use by statute or regulation, or other forest land, which includes less productive forests on which timber is growing at a rate less than $140 \mathrm{~m}^{3} \mathrm{~km}^{-2} \mathrm{yr}^{-1}$. The carbon stocks in trees reflect carbon changes associated with forest management, growth, mortality, harvest, and changes in land use. Thus the forest inventory approach implicitly accounts for emissions due to disturbances such as forest fires. The IPCC definition of SOC includes all organic material in soil to a depth of 1 meter but excludes the coarse roots of the biomass or dead wood pools. Estimates of SOC in forests are based on the spatially disaggregated national State Soil Geographic (STATSGO) database (USDA, 1991), and the general approach described by Amichev and Galbraith (2004).

In Brazil, annual estimates of carbon fluxes were split into four categories: (1) Changes in forest and other woody biomass stocks; (2) Forest conversion to other uses; (3) Abandonment of managed lands; and (4) $\mathrm{CO}_{2}$ emissions and removal from soils. For forest and other woody biomass stocks, only the changes in the stocks of forest planted for economic purposes are considered. Thus changes in carbon stock in native forest that are not a result of LUC were not included in the inventory. For forest conversion to other uses and abandonment of managed lands, the annual LUC areas due to deforestation and regrowth and above-ground biomass 
estimates were applied to calculate net $\mathrm{CO}_{2}$ emissions. The spatial distributions of deforestation and regrowth areas for two different years (1988 and 1994) were obtained through a visual analysis of sampled Landsat satellite images by the National Institute for Space Research (INPE). Major areas of regrowth were found in the Amazon forest $\left(82.3 \times 10^{3} \mathrm{~km}^{2}\right)$ and in the Cerrado $\left(17.7 \times 10^{3} \mathrm{~km}^{2}\right)$. The enhancement of regrowth due to environmental changes may be implicitly included in these estimates, since the satellite images capture only the net area changes due to LUC and thus cannot exclude the changes in forest areas modified by environmental factors (e.g. $\mathrm{CO}_{2}$ fertilization-enhanced production rates of plants in re-growing forest, woody invasion in savanna-like cerrado). The mean estimates of above-ground carbon densities were calculated for each type of vegetation based on data gathered in over 2500 sampled sites, and these densities were overlaid on a vegetation type map. Thus this estimate does not include any time lag due to decay of biomass (i.e. wood products dumped in landfills or burned in incinerators and residuals after slash and burn). In addition to the deforestation, selective harvest of timber occurs in Amazonia to exploit marketable tree species mainly along roads that are useful for log transport. The areas affected by selective logging can be later subject to deforestation or abandonment. Thus double counting of the carbon affected by selective logging can occur when the carbon stock changes due to the deforestation are estimated from the differences between two different years and those due to selective logging are derived from independent methods (e.g. Nepstad et al., 1999; Asner et al., 2005). Because of the need for a more elaborate analysis, $\mathrm{CO}_{2}$ emissions from selective logging have not been explicitly included in this inventory.

EMI2 (EDGAR3; Olivier and Berdowski, 2001) estimated only large-scale vegetation fires (thus no fluxes due to other LUCF) based on FAO reports following the methodology described in the IPCC guidelines (1997). It was assumed that $50 \%$ of the biomass is burned and there were no emissions due to the decay of biomass. For accounting purposes, net $\mathrm{CO}_{2}$ emissions from savanna fires have been assumed to be zero since the vegetation burned in savanna re-grows on a timescale of about one year. It was also assumed that deforestation in industrialized regions occurred primarily during the preindustrial period and most temperate vegetation fires were neglected (van Aardenne et al., 2001).

EMI3 (Hurtt et al., 2006) compiled national wood harvest data and estimated the carbon emission only due to global logging and fuelwood use. Wood harvest was increased by $30 \%$ to account for non-harvested losses on the basis of statistical reports. The harvested wood and additional $30 \%$ were counted as carbon removed from forests.

\subsubsection{Book-keeping models}

Book-keeping models (EMI4 and EMI5) consider the impacts of LUCF, based on reconstructed country/regional historical land use data (Houghton et al., 1983). The detailed methods for simulating the carbon fluxes have been presented in earlier studies (Houghton et al., 1983, 1999, 2000; Houghton and Hackler, 1999, 2003; Houghton, 2003; de Campos et al., 2005).

EMI4 (Houghton, 2006, unpublished) assumed that expanding plantation areas drove deforestation in Latin America so that the values categorized into "afforestation" could be positive (i.e. a net source) in this particular region. EMI4 reanalyzed Africa and included reforestation. Fire suppression leading to woody encroachment and thickening is only considered in the USA (Houghton et al., 1999). Soil degradation is only included in the analysis of China (Houghton and Hackler, 2003).

EMI5 (IVIG; de Campos et al., 2007) uses the same approach as that in de Campos et al. (2005) and is resolved at the country level, but uses carbon contents taken from Jain and Yang (2005). EMI5 consists of two carbon pools (vegetation pools, and 'soil organic carbon' which includes litter pools and soil reservoirs).

\subsubsection{Biogeochemical models}

Biogeochemical models (EMI6 and EMI7) calculate carbon fluxes due to various processes (e.g. photosynthesis, respiration, and decomposition) using physiological relationships driven by environmental factors with moderate simplicity for use in global-scale applications in response to LUC. EMI6 (Sim-CYCLE; Ito and Oikawa, 2002; Kato et al., 2007) contains five components (leaf, stem, root, litter and mineral soil) for application in an integrated earth system model (Kawamiya et al., 2005), while a more recent off-line version treats more components (18 carbon pools; Ito et al., 2006; Ito et al., 2007a). The LUC was based on LUC3. EMI7 (ISAM; Jain and Yang, 2005) considered changes in atmospheric $\mathrm{CO}_{2}$, climate and land cover due to cropland conversions. The LUC was based on SAGE between 1900 and 1992 and extended by linearly extrapolating the cropland fraction at each grid cell and year using the trend for the period between 1985 and 1992. EMI7 consists of eight carbon pools (three vegetation pools, two litter pools and three soil reservoirs).

The carbon dynamics in the soil carbon pools due to LUC are important, especially in the early phase of cultivation, because SOC is often large prior to cultivation and quickly loses a large fraction of the stored $\mathrm{C}$ soon after the initial cultivation (e.g. Janzen et al., 2004). Jones et al. (2005) used the Hadley Centre general circulation model and found that soil $\mathrm{C}$ losses and gains were slower with a multi-pool model (Jenkinson, 1990) than with a single pool model. While the multi-pool model is a major improvement over the 
single-pool model for simulating changes in soil $\mathrm{C}$ stocks (e.g. Knorr et al., 2005), a consensus has not emerged on the applicability of a simple model for use in climate change studies (Davidson and Janssens, 2006). Changes in climate (soil temperature and moisture) can be important for SOC, because the decomposition rates strongly depend on them. In EMI6, these parameters were calculated by a land surface model (MATSIRO; Takata et al., 2003), while in EMI7 the monthly climatic water budget model of Thornthwaite and Mather (1957) as implemented by Pastor and Post (1985) was used. The model-based estimates of SOC pools and fluxes are also sensitive to the self-initialization procedures, which generate the initial states for different combinations of vegetation and climate (Pietsch and Hasenauer, 2006).

Biogeochemical models (EMI6 and EMI7) typically include the effect of $\mathrm{CO}_{2}$ fertilization and climate change, in contrast to book-keeping models. Thus an additional simulation of the Kato et al. (2007) (EMI6) model was performed here to estimate the marginal effect of crop and pasture land establishment and abandonment (McGuire et al., 2001). Results from an additional experiment, where only land cover changes for cropland were varied over a historical time period, were obtained from the Jain and Yang (2005) (EMI7) model, extended to the year of 2000. These simulations enable the models to separate the effects of LUC from those of $\mathrm{CO}_{2}$ fertilization and climate change.

In the coterminous USA, EMI3 (ED model; Hurtt et al., 2002) used a mechanistic ecosystem model to estimate carbon stocks and fluxes. Atmospheric $\mathrm{CO}_{2}$ concentrations and climate conditions were held constant throughout the simulations to focus on the consequences of land-use and firemanagement changes.

Responses of terrestrial ecosystems to climate change are highly complex (e.g., Heimann and Reichstein, 2008; Gruber and Galloway, 2008). We note that none of the three models that we examined accounts for an explicit treatment of the nitrogen cycle, which may determine the magnitude of the $\mathrm{CO}_{2}$ fertilization effect when nitrogen is limiting (Reich et al., 2006; Thornton et al., 2007). Further, the specific rate of heterotrophic respiration (i.e., the respiration rate per unit respiring carbon) is typically assumed to increase with temperature, but there is an ongoing debate about the ecological importance of temperature acclimation, which could offset temperature-induced increases in respiratory activity (Giardini and Ryan 2000; Luo et al. 2001; Knorr et al. 2005).

\subsubsection{Consolidated estimates}

As summarized above, biogeochemical modeling studies can estimate the impacts of (1) $\mathrm{CO}_{2}$ fertilization and climate change in addition to (2) LUC due to crop land conversion and (3) pastureland conversion, while the book-keeping approach includes other processes such as (4) shifting cultivation, (5) harvest of wood, (6) afforestation (e.g. of temperate region grasslands with evergreen trees), (7) fire suppression, and (8) land degradation, which are not considered in biogeochemical models. In addition, other fluxes such as fluxes from (9) urban trees, agricultural soils, and domestic organic refuse can be reported in inventory methods. Here, we developed estimates of terrestrial carbon fluxes (EMI8) due to six of these processes for the 1990s from six data sets for the USA (Table 3 ) and due to seven of these processes from five data sets for Latin America (Table 4). The values in parentheses in the tables were not used for our consolidated data set, because they may include effects, which are not considered by the other data sets (e.g. nitrogen deposition in forests, decay of biomass and wild fires). We also constructed a consolidated estimate of global terrestrial carbon fluxes from five data sets (EMI1, 4, 5, 6, and 7) for the ten regions defined by Houghton (2003): Latin America, Tropical Asia, Tropical Africa, Canada, Europe, Former Soviet Union, China, Pacific Developed Countries, North Africa and Middle East. Technically, the ten regions do not cover the entire global land area, which is treated in the global biogeochemical models (EMI6 and 7). Thus the totals in the ten regions are slightly different from the global totals. However, the differences between the two values are much smaller than those between different data sets. Only net fluxes due to LUC were consolidated because gross LUC (i.e. conversion from non-forest to forest and vice versa) is masked by the aggregation to different resolutions (i.e. region, country, and different grid sizes) and/or by different simplifications adopted in compiling data sets. The consolidated estimates were constructed from the average for each flux category when available for a given data set while the uncertainty range was calculated from the minima and maxima fluxes in each category.

\subsubsection{Inverse models of $\mathrm{CO}_{2}$ fluxes}

In the simplest case, inverse modeling of $\mathrm{CO}_{2}$ fluxes combines atmospheric measurements of the trace gas abundance with a model for atmospheric transport and an a priori estimate of the emission pattern (Enting, 2002). Most measurements used in global atmospheric inversions are made at remote sites far from polluted areas. Although the observed fluctuations in $\mathrm{CO}_{2}$ abundance downwind from a continent give evidence for uptake or emission, the inverse models place no constraint on the cause (e.g. fossil fuel use vs. LUCF) and few constraints in terms of national boundaries. Recent work has evaluated continental-scale net emissions using a wide range of atmospheric models (Gurney et al., 2002, 2004) and extended the inversion to include oceanic measurements, transport, and biogeochemistry (Jacobson et al., 2007). For the most part, current inverse-model estimates of $\mathrm{CO}_{2}$ fluxes are limited by the sparse network of surfacebased observations, although the promise of global spacebased observations may eventually improve the accuracy and resolution of retrieved fluxes (Pak and Prather, 2001; Chevallier et al., 2007). Regional-scale inversions include tower sites (Wang et al., 2007) and intensive aircraft campaigns 


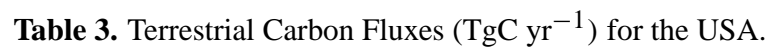

\begin{tabular}{llllllll}
\hline Type of Land Use & EMI1 & EMI3 & EMI4 & EMI5 & EMI6 & EMI7 & EMI8 \\
\hline LULUCF & & & & & & & \\
\hline Crop conversion & $(-187)^{\mathrm{a}}$ & -180 & -4 & 2 & -114 & -29 & -43 \\
Pasture conversion & S.A. $^{\mathrm{b}}$ & S.A. & 0 & S.A. $^{\mathrm{b}}$ & S.A. $^{\mathrm{b}}$ & N.A. $^{\mathrm{c}}$ & S.A. $^{\mathrm{b}}$ \\
Logging \& Fuelwood & S.A. $^{\mathrm{b}}$ & S.A. $^{\mathrm{b}}$ & 27 & N.I. $^{\mathrm{c}}$ & N.I. $^{\mathrm{c}}$ & N.I. $^{\mathrm{c}}$ & S.A. $^{\mathrm{b}}$ \\
Fire suppression & S.A. $^{\mathrm{b}}$ & -150 & -130 & N.I. $^{\mathrm{c}}$ & N.I. $^{\mathrm{c}}$ & N.I. $^{\mathrm{c}}$ & -140 \\
Other LULUCF & -33 & N.I. $^{\mathrm{c}}$ & N.I. $^{\mathrm{c}}$ & N.I. $^{\mathrm{c}}$ & N.I. $^{\mathrm{c}}$ & N.I. $^{\mathrm{c}}$ & -33 \\
\hline Climate and $\mathrm{CO}_{2}$ effect & N.I. $^{\mathrm{c}}$ & N.I. $^{\mathrm{c}}$ & N.I. $^{\mathrm{c}}$ & N.I. $^{\mathrm{c}}$ & -45 & -7 & -26 \\
\hline Total flux & -220 & -330 & -108 & 2 & -159 & -36 & -242 \\
\hline
\end{tabular}

\footnotetext{
a Value in parenthesis reflects carbon changes in forests associated with forest management, growth, mortality, harvest, and changes in land use.

b See Above. Each specific category was combined into a larger category, reported in the row above.

c Not Included.
}

Table 4. Terrestrial Carbon Fluxes $\left(\mathrm{TgC} \mathrm{yr}^{-1}\right)$ for Latin America.

\begin{tabular}{llllllc}
\hline Type of Land Use & EMI1 & EMI4 & EMI5 & EMI6 & EMI7 & EMI8 \\
\hline LULUCF & & & & & & \\
\hline Crop conversion & $(206)^{\mathrm{a}}$ & 236 & 230 & -409 & 124 & 299 \\
Pasture conversion & S.A. $^{\mathrm{b}}$ & 507 & S.A. $^{\mathrm{b}}$ & S.A. $^{\mathrm{b}}$ & N.I. $^{\mathrm{c}}$ & S.A. $^{\mathrm{b}}$ \\
Shifting cultivation & S.A. $^{\mathrm{b}}$ & 30 & N.I. $^{\mathrm{c}}$ & N.I. $^{\mathrm{c}}$ & N.I. $^{\mathrm{c}}$ & 30 \\
Logging \& Fuelwood $^{\mathrm{c}}$ & S.A. $^{\mathrm{b}}$ & -14 & N.I. $^{\mathrm{c}}$ & N.I. $^{\mathrm{c}}$ & N.I. $^{\mathrm{c}}$ & -14 \\
Afforestation & S.A. $^{\mathrm{b}}$ & 34 & N.I. $^{\mathrm{c}}$ & N.I. $^{\mathrm{c}}$ & N.I. $^{\mathrm{c}}$ & 34 \\
Other LULUCF & 20 & N.I. $^{\mathrm{c}}$ & N.I. $^{\mathrm{c}}$ & N.I. $^{\mathrm{c}}$ & N.I. $^{\mathrm{c}}$ & 20 \\
\hline Climate \& $\mathrm{CO}_{2}$ effect & N.I. $^{\mathrm{c}}$ & N.I. $^{\mathrm{c}}$ & N.I. $^{\mathrm{c}}$ & -296 & -781 & -539 \\
\hline Total flux & 226 & 793 & 230 & -706 & -657 & -170 \\
\hline
\end{tabular}

\footnotetext{
a Value in parenthesis reflects carbon changes in forest and other woody biomass stocks, forest conversion to other uses and abandonment of managed lands.

b See Above. Each specific category was combined into a larger category, reported in the row above.

${ }^{\mathrm{c}}$ Not Included.
}

where regional sources are evaluated (Gerbig et al., 2003; Sarrat et al., 2007); however, footprints of these inversions still do not respect national boundaries. In Sect. 3.4, we compare fluxes from inverse models with other estimates for the USA and Latin America.

\section{Results and discussion}

\subsection{Land-use change area}

Figure 1 shows a comparison of the global sum of LUC areas in forests $\left(10^{2} \mathrm{~km}^{2} \mathrm{yr}^{-1}\right)$ due to crop and pasture land conversions over the 1990s. The signs for deforestation are negative (-) and for abandonment positive (+). LUC2 -5 indicate that the increases in forest areas from crop and pasture land abandonment are larger than the decreases in forests areas due to deforestation driven by expansions of crop and pasture land during the 1990s, in contrast to LUC1 and 6. These differences are related to the primary data sets and secondary assumptions. FAOSTAT reported the changes in the agriculture and pasture land at a national scale. HYDE allocated them to a 0.5 degree grid, using a population density map. LUC2 to LUC5 employed the FAOSTAT/HYDE data for their calculations of LUC areas. In these processes, the changes in forest areas are not directly constrained by the measurements, which may include other driving forces such as woody invasions, wild fires and so on. This contrasts with LUC1, which was based on the changes in deforestation areas, and LUC6, which did not use the FAOSTAT/HYDE data based on the comparison between HYDE 


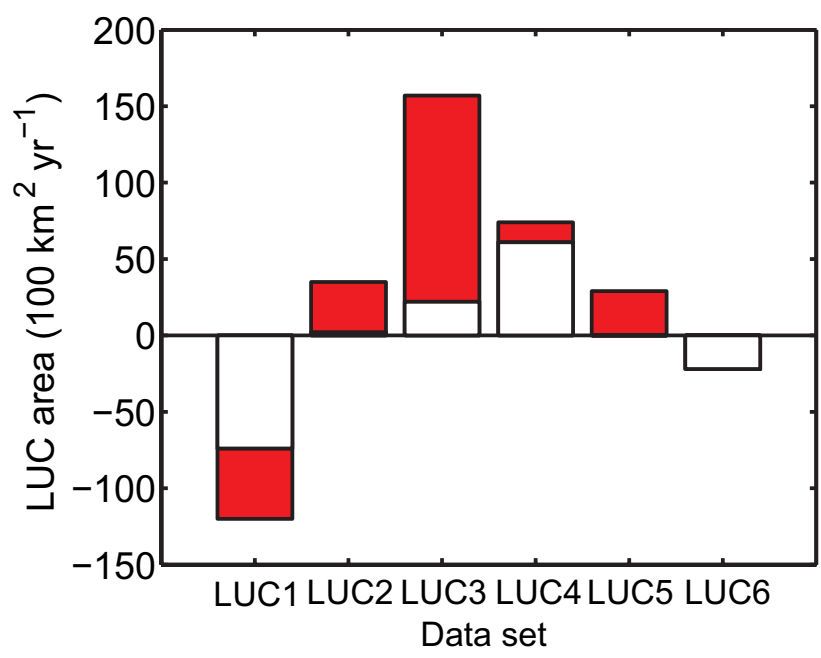

Fig. 1. Comparison of the global sum of land-use change areas in forested areas $\left(10^{2} \mathrm{~km}^{2} \mathrm{yr}^{-1}\right)$ due to crop and pasture land conversions over the 1990s. The negative (-) signs indicate the decreases in forests areas to crop and pasture land and positive (+) signs represent the increases in forests areas from crop and pasture land. The white color represents the crop land conversion. The red color shows the pasture land conversion.

and GLC2000. The latter assumed that the historical expansion of pasture was mostly due to conversion of natural grassland (e.g., Houghton, 1983, 1999, 2003; Klein Goldewijk and Ramankutty, 2004). LUC2 and LUC4 used HYDE and FAOSTAT but show significantly different net changes in forest areas due to crop and pasture land conversions, while the agreement between LUC2 and LUC5 is coincidental, because different primary databases were used. Klein Goldewijk and Ramankutty (2004) assessed the differences between SAGE and HYDE and found that there are major differences due to many different choices: i.e. in the use of a fractional versus single land-use type approach (i.e. grid cells are classified as a single type of land cover), different modeling assumptions, and inventory data sets. Significant differences are found in the net changes in forest areas due to cropland conversions between LUC3, LUC5, and LUC6, all of which used the SAGE data. Even though the same primary data sets may be used by different researchers, secondary data sets have been developed based on different natural vegetation maps, resolutions, and methodologies. In Sect. 3.4.2, the data sets associated with each LUC type in Brazil are analyzed in detail.

\subsection{Carbon pools}

In order to identify major differences in carbon pool changes, carbon pools were collected for each category considered in each LUCF data set. Table 5 presents the global sum of the terrestrial carbon pools $(\mathrm{PgC})$ in the 1990s from EMI4, EMI5, EMI6, and EMI7. Large differences are found in the
Table 5. Global Total Carbon Pools (PgC) During the 1990s.

\begin{tabular}{|c|c|c|c|c|}
\hline Carbon Stocks & EMI4 & EMI5 & EMI6 & EMI7 \\
\hline \multicolumn{5}{|l|}{ Vegetation Carbon (VC) } \\
\hline Above ground vegetation & 516 & 687 & 4 & 90 \\
\hline Woody tree parts & S.A. ${ }^{\mathrm{a}}$ & S.A. ${ }^{\mathrm{a}}$ & 574 & 678 \\
\hline Non woody tree parts (root) & S.A. ${ }^{\mathrm{a}}$ & S.A. ${ }^{\mathrm{a}}$ & 19 & 42 \\
\hline Non woody tree parts (leaf) & S.A. ${ }^{\mathrm{a}}$ & S.A. ${ }^{\mathrm{a}}$ & 118 & S.A. ${ }^{\mathrm{a}}$ \\
\hline Burning associated with LUC & 23 & S.A. ${ }^{a}$ & 0 & 0 \\
\hline Biofuel (wood in use) & S.A. ${ }^{a}$ & S.A. ${ }^{\mathrm{a}}$ & S.A. ${ }^{a}$ & S.A. ${ }^{\mathrm{a}}$ \\
\hline Paper products (wood in use) & S.A. ${ }^{a}$ & S.A. ${ }^{\mathrm{a}}$ & 0 & 1 \\
\hline Long- lived products (wood in use) & S.A. ${ }^{\mathrm{a}}$ & S.A. ${ }^{\mathrm{a}}$ & 1 & 1 \\
\hline Elemental carbon (wood in use) & S.A. ${ }^{\mathrm{a}}$ & S.A. ${ }^{\mathrm{a}}$ & S.A. ${ }^{\mathrm{a}}$ & 1 \\
\hline \multicolumn{5}{|l|}{ Litter (LIT) } \\
\hline Decomposable non-woody material & 15 & 1477 & 95 & 7 \\
\hline Resistant material (woody debris) & S.A. $^{a}$ & S.A. $^{\mathrm{a}}$ & S.A. $^{\mathrm{a}}$ & 471 \\
\hline \multicolumn{5}{|l|}{ Soil Organic Carbon (SOC) } \\
\hline Microbial biomass & 854 & S.A. ${ }^{a}$ & 1415 & 34 \\
\hline Humus organic matter & S.A. ${ }^{\mathrm{a}}$ & S.A. ${ }^{a}$ & S.A. $^{\mathrm{a}}$ & 1314 \\
\hline Global total & 1408 & 2164 & 2227 & 2639 \\
\hline
\end{tabular}

a See Above. Each specific category was combined into a larger category, reported in the row above.

litter (LIT) and soil organic matter categories. The LIT + SOC ranges from 817 to $1796 \mathrm{PgC}$, while vegetation carbon (VC) ranges from 507 to $788 \mathrm{PgC}$. Recent global estimates for the upper one meter of soil indicate about $1500 \mathrm{PgC}$ with a large error associated with the inventory approach (e.g. estimating the mean $\mathrm{C}$ content of any ecologically or taxonomically based mapping unit) (Amundson, 2001). While this estimate is in good agreement with EMI6 and EMI7, EMI7 stores more carbon in LIT as a resistant material (99\% of LIT). Matthews (1997) estimated a global fine litter pool of $80 \mathrm{PgC}$ and coarse woody debris (CWD) of $75 \mathrm{PgC}$ from a measurement compilation. A more recent review of available data on CWD stores and decomposition rates indicates that global stores of carbon in CWD may range between 114 and $157 \mathrm{PgC}$, depending on the estimation procedure (Harmon et al. 2001). Combining the fine litter and CWD yields an inventory-based estimate of LIT (194 to $237 \mathrm{PgC}$ ) that is higher than those of EMI4 (15 PgC) and EMI6 (95 PgC) and lower than that of EMI7 (478 PgC). The carbon pool data for the USA are analyzed in detail in Sect. 3.4.1.

\subsection{Net carbon fluxes and changes in carbon pools}

Table 6 presents terrestrial carbon fluxes for each LULUCF activity considered in the different LULUCF data sets. We note for this comparison that the total of LULUCF fluxes is only for the UNFCCC reporting countries. Thus the totals in Table 6 are slightly different from the global totals in Table 7 but the differences between the two values are much smaller than those between different data sets. Although 
Table 6. Sum of Terrestrial Carbon Fluxes (TgC/yr) From UNFCCC-Reported Countries in the 1990s.

\begin{tabular}{|c|c|c|c|c|c|}
\hline Type of Land Use & EMI1 & EMI4 & EMI5 & EMI6 & EMI7 \\
\hline \multicolumn{6}{|l|}{ LULUCF } \\
\hline Pasture conversion in forest & 113 & 478 & 521 & -465 & N.I. ${ }^{a}$ \\
\hline Pasture conversion in grass land & S.A. ${ }^{b}$ & 1 & S.A. ${ }^{\text {b }}$ & S.A. ${ }^{b}$ & N.I. ${ }^{\mathrm{a}}$ \\
\hline Crop conversion & S.A. ${ }^{\text {b }}$ & 633 & S.A. ${ }^{\text {b }}$ & S.A. ${ }^{\text {b }}$ & 474 \\
\hline Shifting cultivation & S.A. ${ }^{\text {b }}$ & 224 & N.I. ${ }^{\mathrm{a}}$ & N.I. ${ }^{a}$ & N.I. ${ }^{a}$ \\
\hline Afforestation & S.A. ${ }^{b}$ & -93 & N.I. ${ }^{\mathrm{a}}$ & N.I. $^{\mathrm{a}}$ & N.I. ${ }^{\mathrm{a}}$ \\
\hline Soil emission and removal & 9 & N.I. ${ }^{\mathrm{a}}$ & N.I. ${ }^{\mathrm{a}}$ & N.I. ${ }^{\mathrm{a}}$ & N.I. ${ }^{\mathrm{a}}$ \\
\hline Soil degradation & N.I. ${ }^{\mathrm{a}}$ & 2 & N.I. ${ }^{\mathrm{a}}$ & N.I. ${ }^{\mathrm{a}}$ & N.I. ${ }^{a}$ \\
\hline Logging & -362 & 177 & N.I. ${ }^{\mathrm{a}}$ & N.I. ${ }^{\mathrm{a}}$ & N.I. ${ }^{a}$ \\
\hline Fuelwood & S.A. ${ }^{b}$ & 86 & N.I. ${ }^{\mathrm{a}}$ & N.I. ${ }^{\mathrm{a}}$ & N.I. ${ }^{\mathrm{a}}$ \\
\hline Fire suppression & S.A. ${ }^{\text {b }}$ & -122 & N.I. ${ }^{\mathrm{a}}$ & N.I. ${ }^{\mathrm{a}}$ & N.I. ${ }^{\mathrm{a}}$ \\
\hline Other LUCF & 0 & N.I. ${ }^{\mathrm{a}}$ & N.I. ${ }^{\mathrm{a}}$ & N.I. ${ }^{\mathrm{a}}$ & N.I. ${ }^{\mathrm{a}}$ \\
\hline \multicolumn{6}{|l|}{ ENV } \\
\hline Climate \& $\mathrm{CO}_{2}$ effect in forest & N.I. ${ }^{\mathrm{a}}$ & N.I. ${ }^{\mathrm{a}}$ & N.I. ${ }^{\mathrm{a}}$ & -690 & -1432 \\
\hline Climate \& $\mathrm{CO}_{2}$ in non-forest & N.I. ${ }^{\mathrm{a}}$ & N.I. ${ }^{\mathrm{a}}$ & N.I. ${ }^{\mathrm{a}}$ & -238 & S.A. ${ }^{b}$ \\
\hline Sum in UNFCCC-reported countries & -240 & 1386 & 521 & -1393 & -958 \\
\hline
\end{tabular}

a Not Included.

b See Above. Each specific category was combined into a larger category, reported in the row above.

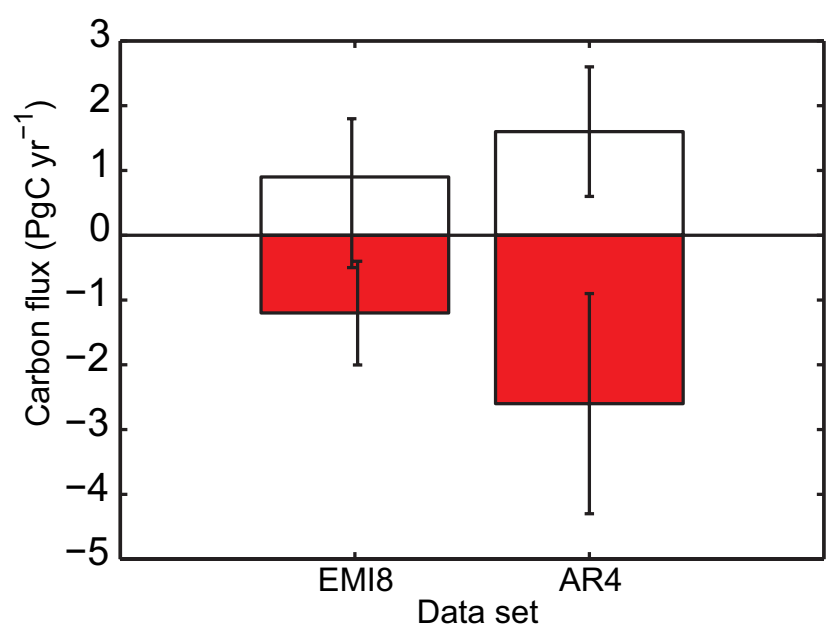

Fig. 2. Comparison of global land-use change fluxes and residual terrestrial sinks $\left(\mathrm{PgC} \mathrm{yr}^{-1}\right)$ in the 1990s. The sign for removal is negative (-) and that for emissions positive (+). The white color represents LUCF. The red color shows ENV.

137 non-Annex I countries report total carbon fluxes, only 19 non-Annex I countries provide detailed carbon fluxes. Therefore, the total carbon fluxes for specific categories in EMI1 were calculated for the non-Annex I countries by scaling each country's total fluxes by the averaged ratios of the specific categories' fluxes to the total for the 19 countries.

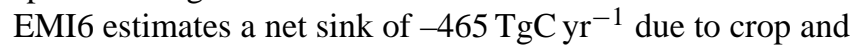

pasture land conversions, while EMI7 shows the net emis-

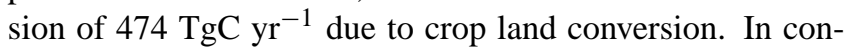
trast to the other data sets, both EMI6 and EMI7 include the effects of environmental changes on fluxes of carbon. Even though EMI6 and EMI7 consider different activities and their net fluxes are large and of opposite sign, the sums of their fluxes from all categories are in better agreement (i.e. -1393 and $-958 \mathrm{TgC}^{-1}{ }^{-1}$ for EMI6 and EMI7, respectively). These comparisons demonstrate the need to reconcile the different processes considered in different data sets.

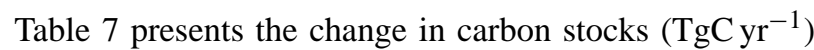
for EMI5, EMI6, and EMI7 and the net carbon fluxes for EMI2, EMI3, and EMI4 for each pool considered in the different LUCF data sets in the 1990s. We note that carbon stock changes in a single pool are not necessarily equal to the emission or removal of $\mathrm{CO}_{2}$ from the atmosphere, because some carbon stock changes result from carbon transfers among pools rather than exchanges with the atmosphere. Even though the total fluxes are in good agreement between EMI6 and EMI7, this does not indicate good agreement, because the relative contributions of the VC, LIT, and SOC are significantly different between these data sets. These comparisons demonstrate the necessity of reconciling the different classifications of carbon pools used in the different data sets. 
Table 7. Global Total Carbon Stock Changes (TgC/yr) for EMI5, 6, and 7 and Global Net Carbon Fluxes for EMI2, 3 , and 4 in the 1990s.

\begin{tabular}{|c|c|c|c|c|c|c|}
\hline Carbon Stock Changes & EMI2 & EMI3 & EMI4 & EMI5 & EMI6 & EMI7 \\
\hline \multicolumn{7}{|l|}{ Vegetation Carbon (VC) } \\
\hline Above ground vegetation & N.I. ${ }^{\mathrm{a}}$ & N.I. ${ }^{\mathrm{a}}$ & -2388 & 287 & 12 & -236 \\
\hline Woody tree parts & N.I. ${ }^{\mathrm{a}}$ & N.I. ${ }^{\mathrm{a}}$ & S.A. ${ }^{b}$ & S.A. ${ }^{b}$ & -802 & -404 \\
\hline Non woody tree parts (leaf) & N.I. ${ }^{\mathrm{a}}$ & N.I. ${ }^{\mathrm{a}}$ & S.A. ${ }^{b}$ & S.A. ${ }^{b}$ & 8 & -63 \\
\hline Non woody tree parts (root) & N.I. ${ }^{\mathrm{a}}$ & N.I. ${ }^{\mathrm{a}}$ & S.A. ${ }^{b}$ & S.A. ${ }^{b}$ & -213 & S.A. ${ }^{\text {b }}$ \\
\hline Burning associated with LUC & N.I. ${ }^{\mathrm{a}}$ & N.I. ${ }^{\mathrm{a}}$ & 1996 & S.A. ${ }^{b}$ & 10 & 0 \\
\hline Biofuel (wood in use) & N.I. ${ }^{\mathrm{a}}$ & N.I. ${ }^{\mathrm{a}}$ & S.A. ${ }^{b}$ & S.A. ${ }^{b}$ & S.A. ${ }^{b}$ & S.A. ${ }^{b}$ \\
\hline Paper products (wood in use) & N.I. $^{\mathrm{a}}$ & N.I. ${ }^{\mathrm{a}}$ & S.A. ${ }^{b}$ & S.A. ${ }^{b}$ & 85 & 29 \\
\hline Long- lived products (wood in use) & N.I. ${ }^{\mathrm{a}}$ & N.I. ${ }^{\mathrm{a}}$ & S.A. ${ }^{b}$ & S.A. ${ }^{b}$ & 12 & 8 \\
\hline Elemental carbon (wood in use) & N.I. ${ }^{a}$ & N.I. ${ }^{\mathrm{a}}$ & S.A. ${ }^{\mathrm{b}}$ & S.A. ${ }^{\text {b }}$ & S.A. ${ }^{\text {b }}$ & -2 \\
\hline Litter (LIT) & N.I. ${ }^{\mathrm{a}}$ & N.I. $^{\mathrm{a}}$ & & & & \\
\hline Decomposable non-woody material & N.I. ${ }^{\mathrm{a}}$ & N.I. ${ }^{\mathrm{a}}$ & 1744 & 233 & -6 & 16 \\
\hline Resistant material (woody debris) & N.I. ${ }^{\mathrm{a}}$ & N.I. ${ }^{\mathrm{a}}$ & S.A. ${ }^{b}$ & S.A. ${ }^{b}$ & S.A. ${ }^{b}$ & -232 \\
\hline Soil Organic Carbon (SOC) & N.I. ${ }^{\mathrm{a}}$ & N.I. ${ }^{\mathrm{a}}$ & & & & \\
\hline Microbial biomass & N.I. ${ }^{\mathrm{a}}$ & N.I. ${ }^{\mathrm{a}}$ & 213 & S.A. ${ }^{b}$ & -7 & -19 \\
\hline Humus organic matter & N.I. ${ }^{\mathrm{a}}$ & N.I. ${ }^{\mathrm{a}}$ & S.A. ${ }^{\mathrm{b}}$ & S.A. ${ }^{\text {b }}$ & S.A. ${ }^{\text {b }}$ & -157 \\
\hline Global total & N.I. ${ }^{\mathrm{a}}$ & N.I. $^{\mathrm{a}}$ & 1566 & 521 & -900 & -1059 \\
\hline Open vegetation burning & 485 & N.I. ${ }^{\mathrm{a}}$ & N.I. ${ }^{\mathrm{a}}$ & N.I. ${ }^{\mathrm{a}}$ & N.I. $^{\mathrm{a}}$ & N.I. ${ }^{\mathrm{a}}$ \\
\hline Harvested wood products & N.I. ${ }^{\mathrm{a}}$ & 1305 & N.I. ${ }^{\mathrm{a}}$ & N.I. ${ }^{\mathrm{a}}$ & N.I. $^{\mathrm{a}}$ & N.I. ${ }^{\mathrm{a}}$ \\
\hline
\end{tabular}

a Not Included.

${ }^{\mathrm{b}}$ See Above. Each specific category was combined into a larger category, reported in the row above.

Figure 2 shows a comparison of the global consolidated

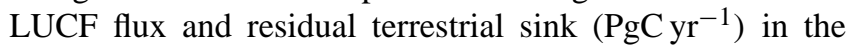
1990s with the estimates from AR4 (Denman et al., 2007). The global flux for EMI8 was calculated by summing the consolidated estimates from the ten regions (see Sect. 2.2.4) that are represented in all data sets. The EMI8 estimate of LUCF emissions ( $\left.0.9 \mathrm{PgC} \mathrm{yr}^{-1}\right)$ is smaller than that from AR4 but within the uncertainty range given in that assessment $\left(1.6 \pm 1.2 \mathrm{PgC} \mathrm{yr}^{-1}\right)$ which was based on the higher values of Houghton (2003) and the lower of DeFries et al. (2002). The satellite estimate of carbon flux in the tropics due to LUC (0.95 $\mathrm{Pg} \mathrm{C} \mathrm{yr}^{-1}$ ) (Achard et al., 2002, 2004; DeFries et al., 2002) is significantly smaller than the FAObased estimate of 2.3 $\mathrm{Pg} \mathrm{C} \mathrm{yr}^{-1}$ (Fearnside, 2000; Houghton, 2003). The EMI8 estimate of the global net terrestrial car-

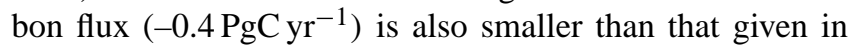
the AR4 assessment but is within their uncertainty range $\left(-1.0 \pm 0.6 \mathrm{PgC} \mathrm{yr}^{-1}\right)$. This confirms that at the global level, our estimate is reasonable for further analysis, although this is not a validation of the consolidated estimate. The AR4 estimate of the residual terrestrial sink $\left(-2.6 \pm 1.7 \mathrm{TgC}^{-1}\right)$ is determined by subtraction of the LUC emissions from the net land-to-atmosphere flux estimated by inverse models and includes both climate feedback and $\mathrm{CO}_{2}$ fertilization effects (which are of order $-1.2{\mathrm{PgC} \mathrm{yr}^{-1}}^{-1}$ in EMI8), as well as nitrogen fertilization and other effects.

\subsection{Country analysis}

\subsubsection{USA}

A more detailed analysis is presented here for the USA. Figure 3 presents the sum of the terrestrial carbon pools $(\mathrm{PgC})$ in the 1990s for EMI1, 4, 5, 6, and 7. Major differences are found in the LIT and SOC pools. The total soil organic matter is much smaller in the National inventory report to the UNFCCC (EMI1) than those in the other estimates. The inventory data in EMI1 are reported only for the category of forest land remaining as forest land, while the other EMI estimates include non-forested lands. The different estimated amounts of SOC are partly due to the inclusion of non-forested lands. Guo et al. (2006) used the STATSGO database to estimate the SOC in the upper $1.0 \mathrm{~m}$ of the conterminous USA as in the USA report (EMI1) and restricted their 


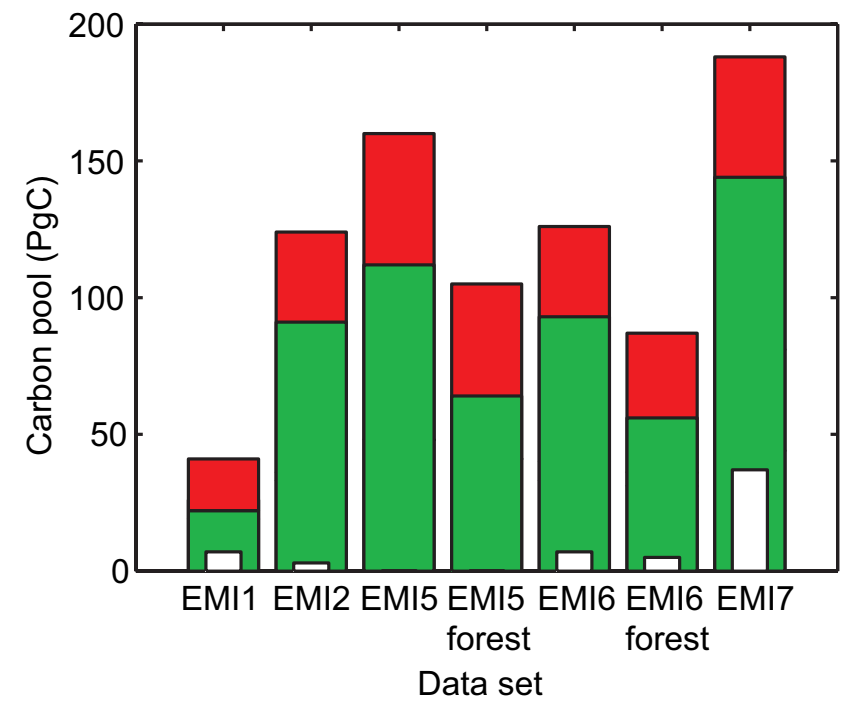

Fig. 3. Comparison of the sum of terrestrial carbon pools $(\mathrm{PgC})$ for the USA in the 1990s. The white color represents the LIT when LIT is separated from SOC. The green color shows the SOC + LIT. The red color denotes the $\mathrm{VC}$.

analysis to forested lands by overlaying the geo-referenced national land cover data (NLCD) based on $30 \mathrm{~m}$ resolution Landsat Thematic Mapper data acquired in the early 1990s with the STATSGO. In the NLCD, forestlands were divided into two parts: forested upland $\left(228 \times 10^{4} \mathrm{~km}^{2}\right)$ and woody wetlands $\left(21 \times 10^{4} \mathrm{~km}^{2}\right)$. The total forest area is in good agreement with the Forest Inventory Analysis (FIA) forest area used in EMI1, but smaller than LUC3 $\left(551 \times 10^{4} \mathrm{~km}^{2}\right)$ and LUC6 $\left(338 \times 10^{4} \mathrm{~km}^{2}\right)$. The SOC value from EMI1 $(15 \mathrm{PgC})$ is within the range for forested upland and woody wetlands reported by Guo et al. (2006) (i.e. 8.5 to $42.5 \mathrm{PgC}$ ). The other model estimates are within the range from 25.4 to 113.1 PgC for total lands reported by Guo et al. (2006). EMI5 and EMI6 make separate estimates of the SOC pool for the forest carbon pools. Their contributions from nonforest lands (36 PgC for EMI6) partly offset the differences in the totals shown in Fig. 3. When Alaska is separated from the conterminous USA in EMI6, the SOC in forests of the conterminous USA is calculated to be 39 PgC. EMI6 uses a potential vegetation map, so that the forest area in EMI6 is larger than the present-day FIA forest area. In addition, Guo et al. (2006) estimated an additional 2.3 to $16.4 \mathrm{PgC}$ in the amount of SOC stored from $1.0 \mathrm{~m}$ to $2.0 \mathrm{~m}$ depth for forest and wetland. The SOC below $1.0 \mathrm{~m}$ may explain some of the differences in SOC between EMI1and EMI6. Consequently, SOC reported by EMI6 may be similar to that for EMI1 if comparison is restricted to the upper $1.0 \mathrm{~m}$ of soils in present-day forests within the conterminous USA. Although those from the other inventories are still large compared to EMI1, they should be compared for the same depth and forest area. Coarse woody debris (92\% of LIT) is rather large

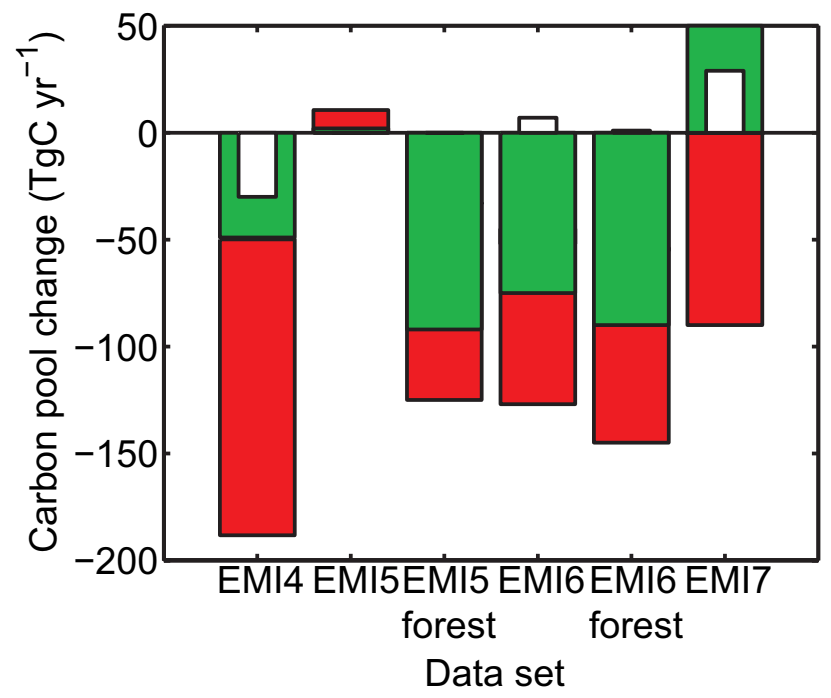

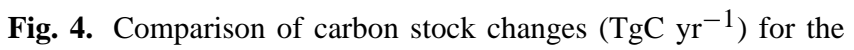
USA in the 1990s. The white color represents the LIT when LIT is separated from SOC. The green color shows the SOC + LIT. The red color denotes the VC.

in EMI7 and as large as woody tree parts (VC). Harmon and Hua (1991) report that the ratio of CWD to live wood biomass is about $20-25 \%$ for subtropical, temperate, and boreal forests, which is consistent with EMI1.

Figure 4 presents carbon stock changes for EMI1, 5, 6 and 7. The inventory data from EMI1 represent only forests including VC, LIT and SOC. The contributions of carbon stock changes for non-forests are insignificant for EMI6, because woody invasions into grasslands are not considered in this model. On the other hand, significant differences in the carbon fluxes in forest lands and all lands are found for EMI5 mainly due to LUC emissions in cultivated areas and pasturelands. The averaged carbon stock changes for forests show an accumulation of carbon in LIT + SOC for EMI1 $\left(-49 \mathrm{TgC} \mathrm{yr}^{-1}\right)$, EMI5 $\left(-92 \mathrm{TgC} \mathrm{yr}^{-1}\right)$ and EMI6 $\left(-90 \mathrm{TgC} \mathrm{yr}^{-1}\right)$, as opposed to EMI7 which reports $51 \mathrm{TgC} \mathrm{yr}^{-1}$ for all land cover types. Litter in EMI1 increases as the tree biomass increases, because estimates for dead wood are based on the ratio of downed dead wood to live tree biomass, while that in the process-based models does not increase linearly with tree biomass, but is determined by the models calculations, which depend on the changes in climate (soil temperature and moisture).

Table 3 presents terrestrial carbon fluxes for each LUCF activity considered in the different LUCF data sets for the USA in the 1990s. We note that EMI3 represents the data of Hurtt et al. (2002) for this analysis in the USA. Only EMI2, 3 and 4 include the effects of fire suppression on LUCF fluxes, but EMI1 excludes woody encroachment in non-forests. The terrestrial carbon flux in EMI4 $\left(-108 \mathrm{Tg} \mathrm{Cyr}^{-1}\right)$ is in good agreement with that of EMI6 


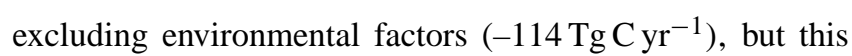
agreement is fortuitous, because there is a large sink in EMI4 due to fire suppression $\left(-130{\mathrm{TgC} \mathrm{yr}^{-1}}^{-1}\right.$ which is not considered in EMI6. The overall fire suppression sink in EMI4 for the 1980s $\left(-155 \mathrm{TgC}^{-1}\right)$ is in good agreement with that

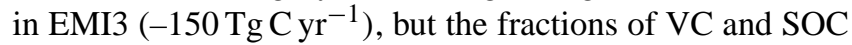
could be different, because the changes in SOC associated with woody encroachment are assumed to be negligible in EMI4. When the comparison is restricted to forested lands,

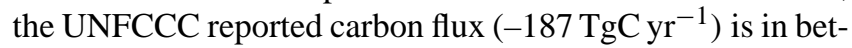

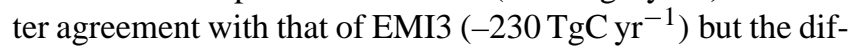
ference is non-negligible. The sinks due to $\mathrm{CO}_{2}$ fertilization

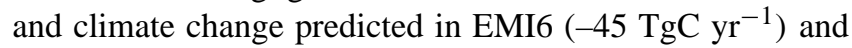
EMI7 ( $\left.-7 \mathrm{TgC} \mathrm{yr}^{-1}\right)$ are relatively minor components, which is consistent with Caspersen et al. (2000) who used the FIA data to estimate the effects of environmental factors.

We compare inverse model fluxes for Temperate North America (TNA) (including the conterminous USA, most of Mexico, and southern Canada) with the bottom-up inventories examined here for the USA, under the assumption that most of the estimated inverse flux would be associated with the USA (Table 8). In Gurney et al. (2004) the net biospheric flux for TNA for $1992-1996$ is $-0.9 \mathrm{PgC} \mathrm{yr}^{-1}$, while more recent updates (Baker et al., 2006) give $-1.1 \pm 0.23 \mathrm{PgC} \mathrm{yr}^{-1}$ for the decade 1991-2000. Depending on the use of all sites (i.e. ocean and land) versus only ocean observations, Patra et al. (2006) estimated the TNA sink in the range from 0.56 to $-0.69 \mathrm{PgC} \mathrm{yr}^{-1}$ for the period 1999-2001. Based on many models' inability to match observed $\mathrm{CO}_{2}$ profiles, Stephens et al. (2007) argue for 38\% smaller uptake fluxes over northern lands but do not report values for TNA. These fluxes have the fossil-fuel and industrial sources removed and represent the sum of changes due to LUCF and the environment $\left(\mathrm{CO}_{2}\right.$ and nitrate fertilization, $\mathrm{O}_{3}$ damage (Sitch et al., 2007), and climate). The decadal averaged estimate for the total terrestrial uptake for TNA (Baker et al., 2006) is significantly larger than the sum of our consolidated estimate (-0.24 $\mathrm{PgC} \mathrm{yr}^{-1}$ averaged over 1990-1999; EMI8) and other sinks such as carbon accumulated in sediments of reservoirs and rivers and the balance of exports and imports by rivers and commerce (e.g. food and wood) $(-0.08$ to $-0.17 \mathrm{PgC} \mathrm{yr}^{-1}$; Pacala et al., 2001). Examining this result together with the significant uncertainties in carbon pools and fluxes for non-forests (e.g. woody invasion) may imply that ENV factors (i.e. warming climate and fertilization) have played a larger role than estimated in EMI8.

\subsubsection{Brazil}

Figure 5 shows a comparison of the net LUC area changes in forests $\left(10^{2} \mathrm{~km}^{2} \mathrm{yr}^{-1}\right)$ due to conversion of forest to/from crop and pasture land in Brazil in 1990. Comparison of LUC3 and LUC6 both of which are based on SAGE for cropland conversions shows that the LUC3 net increase in forest areas $\left(63 \times 10^{2} \mathrm{~km}^{2} \mathrm{yr}^{-1}\right)$ due to cropland conversion

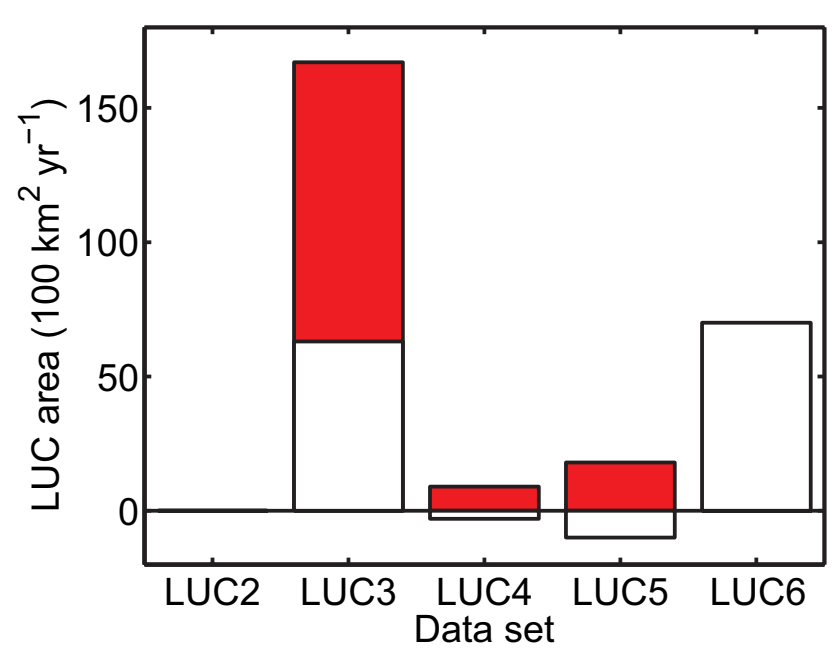

Fig. 5. Comparison of the net land-use area changes. The white color represents the conversin of forest to/from crop land and the red color shows the conversion of forest to/from pasture. The signs for deforestation are negative (-) and for abandonment positive (+).

Table 8. Comparison of Terrestrial Carbon Fluxes $\left(\mathrm{TgC} \mathrm{yr}^{-1}\right)$ From the Top-Down Estimates for the Temperate North America and Bottom-Up Estimates for the USA.

\begin{tabular}{lll}
\hline Study & C Flux & Method \\
\hline Baker et al. (2006) & $-1.1 \pm 0.23$ & Inverse model \\
Gurney et al. (2004) & -0.9 & Inverse model \\
Patra et al. (2006) & -0.56 to -0.69 & Inverse model \\
This work $^{\mathrm{a}}$ & -0.32 to -0.41 & Consolidated data \\
\hline
\end{tabular}

a Sum of EMI8 and other sinks estiamted by Pacala et al. (2001).

is consistent with that in LUC6 $\left(70 \times 10^{2} \mathrm{~km}^{2} \mathrm{yr}^{-1}\right)$. However, the sum of the gross decrease in forest and grassland areas in LUC3 $\left(-29 \times 10^{2} \mathrm{~km}^{2} \mathrm{yr}^{-1}\right)$ due to conversion of forest to crop and pasture land is smaller than that in LUC6 $\left(-34 \times 10^{2} \mathrm{~km}^{2} \mathrm{yr}^{-1}\right)$ from 1989 to 1990 in Brazil. The difference is mainly due to the simple interpolation to T42 in the case of LUC3, because the estimate was $-34 \times 10^{2} \mathrm{~km}^{2} \mathrm{yr}^{-1}$ on the original grid. Further, the gross decrease in forests in LUC3 $\left(-28 \times 10^{2} \mathrm{~km}^{2} \mathrm{yr}^{-1}\right)$ due to crop and pasture land conversions is larger than that in LUC6 $\left(-8 \times 10^{2} \mathrm{~km}^{2} \mathrm{yr}^{-1}\right)$ due to crop land conversion from 1989 to 1990 in Brazil. Therefore, LUC3 accounts for major deforestation due to LUC, as opposed to LUC6. As a result, the net change due to LUC in Fig. 5 is similar but the gross deforestation is different. Regarding the conversion of

natural forests to cropland, there are two major reasons that could cause differences between the data sets: (1) the satellite based classifications used for the present-day natural vegetation cover versus classification based on ground observations and (2) the use of fractional natural plant functional 


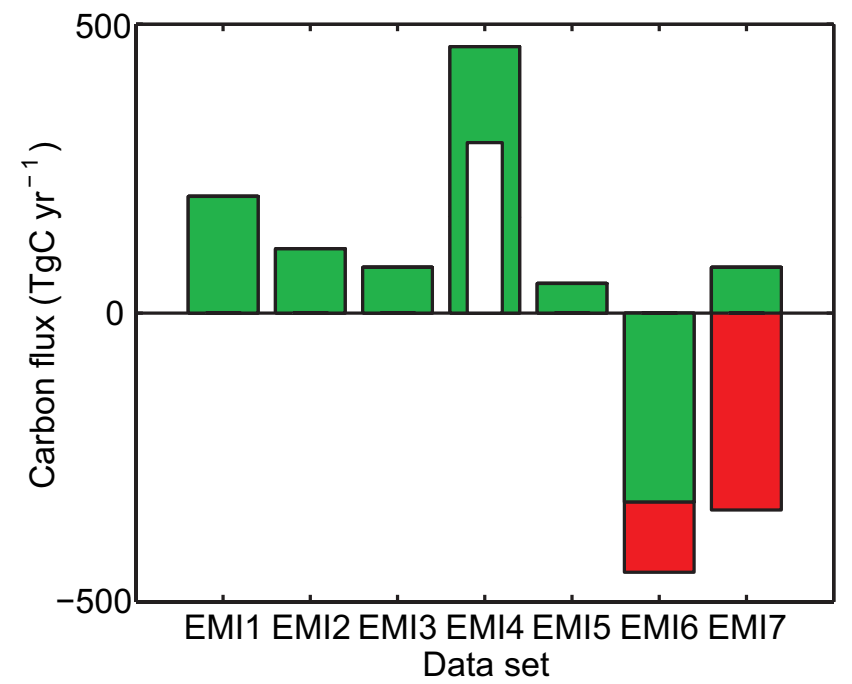

Fig. 6. Comparison of terrestrial carbon fluxes $\left(\mathrm{TgC} \mathrm{rr}^{-1}\right)$ for each land-use activity for Brazil in the 1990s. The white color represents the pasture conversion when pasture is separated from LUCF. The green color shows total LUCF. The red color denotes the biospheric response due to $\mathrm{CO}^{2}$ fertilization and climate change.

types (PFTs) versus a single land-use type approach for each grid area. The first factor determines what types of natural vegetation were assumed to exist on the Earth's surface (e.g. forests, grasses or bare land), which could vary between different data sources. In LUC6, the GLC2000 data set (Eva et al., 2004) was combined with 1992 satellite data, and the grid cells were adjusted to have the same fractions of tree covered land, bare ground and inland water as in GLC2000 and to have the same cropland and grassland fractions as in 1992. In the biogeochemical models (EMI6 and EMI7), forest grid cells may include non-forest areas, but they are treated as forests. LUC3 uses the simplified vegetation map from the Matthews (1983) global ecosystem data set. Moreover, these data are significantly different from those reported by LUC5 which includes secondary forest based on SAGE and other sources, mainly because LUC5 used a linear interpolation between 1970 and 1990, while other data sets used a database based on a single year. As opposed to LUC5, the LUC3 and LUC6 data sets did not track LUC activities, and therefore they represent a "net" change of areas associated with tree PFTs that were converted to cropland area, i.e. the primary (or secondary) forest area that was converted to crops, minus any crop (and pasture) area converted back to secondary forest. Areas converted from crop and pasture could include both active human conversions (e.g. short-rotation forestry in Brazil) and the passive reversion of abandoned crop or pasture land to "natural" (but possibly degraded) forest. The errors implicit in this approach might have significant impacts on carbon dynamics resulting from the changes in land cover at small spatial scales and short-term durations. LUC2 and LUC4 show small net changes in LUC areas.
LUC4 in the 1990s presents substantial gross changes of deforestation $\left(-73 \times 10^{2} \mathrm{~km}^{2} \mathrm{yr}^{-1}\right)$ and $\mathrm{AR}$ $\left(79 \times 10^{2} \mathrm{~km}^{2} \mathrm{yr}^{-1}\right)$, while LUC2 assigned all the changes in cropland areas to non-forest conversions and thus has a zero net change in forest areas. Even though LUC2, LUC4 and LUC5 use the FAOSTAT for crop and pasture lands, the net forest area changes in LUC2 (zero), LUC4 $\left(6 \times 10^{2} \mathrm{~km}^{2} \mathrm{yr}^{-1}\right)$, and LUC5 $\left(7 \times 10^{2} \mathrm{~km}^{2} \mathrm{yr}^{-1}\right)$ in the 1990s are substantially smaller than that for 1990-2000 reported by FAO (2006) $\left(-268 \times 10^{2} \mathrm{~km}^{2} \mathrm{yr}^{-1}\right)$. According to Araújo et al. $\left(2007^{3}\right)$, the allocations of deforestated areas due to pasture and agriculture expansions in HYDE used by de Campos et al. (2005) do not match those in INPE, primarily due to differences between the HYDE and INPE databases in the basic methodology and the concept of deforestation. These comparisons demonstrate the need to constrain the rate of conversions of natural forest areas in each specific LUC activity for the calculation of LUC.

Figure 6 presents terrestrial carbon fluxes $\left(\mathrm{TgC} \mathrm{yr}^{-1}\right)$ for each LUCF activity considered in the different emission data sets for Brazil in the 1990s. EMI4 shows a major source of carbon fluxes to the atmosphere due to forest conversion to pasture. Carbon fluxes due to land conversions are oppo-

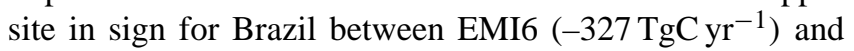
EMI7 (79 $\mathrm{TgC}_{\mathrm{yr}}^{-1}$ ). The SAGE data show high-clearing rates in eastern Brazil during 1960-1980 and extensive cropland abandonment during 1980-1992 except for southeastern Brazil. When the comparison is restricted to the early 1990s, because different secondary assumptions are used for land cover changes in the 1990s, EMI6 indicates a 500 $\left(\mathrm{TgC} \mathrm{yr}^{-1}\right)$ sink due to LUC, while EMI7 shows extensive emissions due to conversion of forest to cropland during the same period. This might be partly due to the inclusion of pasture land conversion, because the net forest area change $\left(104 \times 10^{2} \mathrm{~km}^{2}\right)$ due to pasture conversion is larger than that due to crops in LUC3 (Fig. 5). Since FAO (2006) reports a decrease in forest areas in Brazil between 1990 and 2000, the positive sign (i.e. net source) in EMI4, which is based on FAO (2006), is consistent with EMI7, which did not use the HYDE data set. The emissions in inventory approaches (EMI1, 2, and 3) are not directly comparable to the other emissions shown in Fig. 6, because there is a time delay in emissions into the atmosphere that are accounted for only in EMI4, 5, 6 and 7. The annual gross emission due to deforestation in EMI1 can be compared with that in EMI2, as follows. If we assume that $100 \%$ of the above-ground biomass in EMI2 is immediately removed from the forest as in EMI1, the gross emissions due to deforestation are in better agreement between EMI1 (251 $\left.\mathrm{TgC}^{-1}{ }^{-1}\right)$ and EMI2 $\left(222 \mathrm{TgC}^{-1}\right)$ as well as the deforestation area between the

\footnotetext{
3 Araújo, M. S. M., Silva, C., and Campos C. P.: Land use change sector contribution to the carbon historical emissions and the sustainability case study of the Brazilian Legal Amazon, Renewable Sustainable Rev., accepted, 2007.
} 
INPE report $\left(-313 \times 10^{2} \mathrm{~km}^{2} \mathrm{yr}^{-1}\right)$ from 1988 to 1994 and that from FAO (1993) $\left(-367 \times 10^{2} \mathrm{~km}^{2} \mathrm{yr}^{-1}\right)$ from 1981 to 1990. EMI1 does not account for the fate of the carbon removed from the forests. Assuming that the carbon is either emitted to the atmosphere or harvested, combining the emissions to the atmosphere in EMI2 $\left(111 \mathrm{TgC} \mathrm{yr}^{-1}\right)$ and the harvested wood including slash in EMI3 $\left(79{\left.\mathrm{TgC} \mathrm{yr}^{-1}\right)}^{-1}\right.$ yields a smaller gross emission due to deforestation than that in EMI1 (251 $\left.\mathrm{TgC} \mathrm{yr}^{-1}\right)$. However, Asner et al. (2005) reported that selectively logged areas ranged from 121 to 198 $\left(\times 10^{2} \mathrm{~km}^{2} \mathrm{yr}^{-1}\right)$ between 1999 and 2002 , equivalent to 60 to $123 \%$ of the deforestation area reported by INPE. This may suggest that selective logging has been implicitly taken into account in the net emissions since the selective logging area could have been deforested or regenerated between the years 1988 and 1994 when satellite estimates were possible. In Brazil, climate and $\mathrm{CO}_{2}$ responses are significantly different between EMI6 and EMI7, whereas they were insignificant in the USA.

We can compare the available inverse model fluxes for Tropical $\left(1.07 \pm 0.69 \mathrm{PgC} \mathrm{yr}^{-1}\right)$ and South America $\left(-0.64 \pm 0.51 \mathrm{PgC} \mathrm{yr}^{-1}\right)$ from Baker et al. (2006) with our consolidated bottom-up method for the decade 1991-2000. Patra et al. (2006) estimated a smaller Tropical source $(0.50$ to $\left.0.55 \mathrm{PgC} \mathrm{yr}^{-1}\right)$ and a smaller Temperate sink ( -0.16 to $0.01 \mathrm{PgC}^{-1}$ ), although their combined emissions from Tropical and Temperate America are consistent with those from Baker et al. (2006). The total net emission for Latin America in EMI8 $\left(-0.17 \mathrm{PgC} \mathrm{yr}^{-1}\right)$ is smaller than that from the inverse models $\left(0.43 \pm 0.86 \mathrm{PgC} \mathrm{yr}^{-1}\right)$ but within the uncertainty range. The estimate of total LUC emissions in EMI8 (0.4 $\left.\mathrm{PgC} \mathrm{yr}^{-1}\right)$ during the 1990 s is in between the estimates of Achard et al. (2004) $\left(0.3 \mathrm{PgC} \mathrm{yr}^{-1}\right)$ and DeFries et al. (2002) $\left(0.5 \mathrm{PgC} \mathrm{yr}^{-1}\right)$. The interannual variability of $\mathrm{CO}_{2}$ flux in EMI8 for Latin America (Fig. 7) is significantly smaller than the inverse estimates (Baker et al., 2006). The bottom-up estimates of LUCF may capture the averaged changes of the net LUCF emissions but may not fully account for the timing of $\mathrm{CO}_{2}$ flux changes. Further, there are significant uncertainties in selective logging (e.g. Nepstad et al., 1999; Asner et al., 2005) and open vegetation burning (e.g. van der Werd et al., 2004; Jain et al., 2006; Ito et al., 2007b). This may imply that accurate estimates of the shortterm flux would play a key role in closing the gap between the bottom-up and top-down estimates.

\section{Summary and conclusions}

There are large differences in the processes included in different LUCF data sets at the global level. Thus, model estimates for LUCF emissions without climate feedback range from -0.5 to $1.4 \mathrm{PgC} \mathrm{yr}^{-1}$. The Houghton et al. (2006) emissions are the highest of these emissions but this data set includes the most complete set of LUCF processes. Because

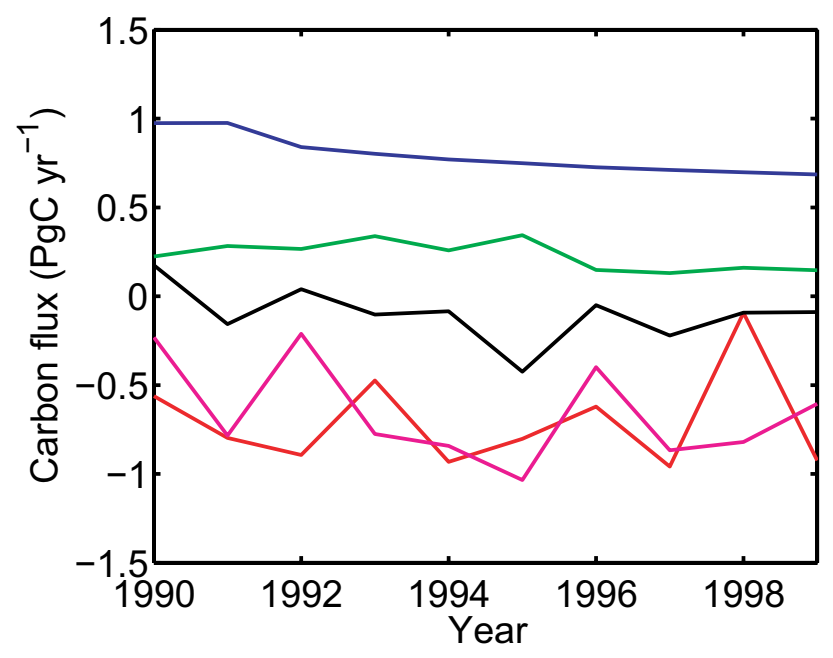

Fig. 7. Interannual variability in LUCF emissions for EMI4 (blue), EMI5 (green) and terrestrial carbon fluxes $\left(\mathrm{PgC} \mathrm{rr}^{-1}\right)$ for EMI6 (red), EMI7 (magenta) and EMI8 (black) for Latin America.

there are different sources of errors at the country level, a country specific approach with spatial and temporal detail is needed to reconcile different estimates of carbon fluxes. Specific issues that will need to be addressed for the USA data for LUCF emissions include a more accurate quantification of the SOC and the changes in carbon stock due to the effects of fire suppression as well as a better constraint on estimates of the long-term ENV. Specific issues that will need to be focused on to improve the Brazilian data for LUCF emissions include a more accurate quantification of the rate of deforestation and AR in each specific LUC activity.

We constructed a consolidated estimate of global LULUCF fluxes from different processes which used the Houghton et al. (2006) estimates if not included in the other models and an average of the estimates for each process when independent data sets were available. This yields a global estimate for LUCF emissions of $0.9 \mathrm{PgC} \mathrm{yr}^{-1}$ for the 1990s. The global estimate of LUCF emissions in the consolidated estimate (i.e. 0.9 with a range from -0.6 to $\left.1.8 \mathrm{Pg} \mathrm{yr}^{-1}\right)$ is compatible with AR4 assessment $\left(1.6 \pm 1.2 \mathrm{PgC} \mathrm{yr}^{-1}\right)$. Overall, climate feedback and fertilization effects could significantly decrease the net global emissions from LUCF, but more research will be needed to better quantify these effects. Climate feedback and fertilization effects in the 2 biogeochemical cycle models reviewed here lead to a $\mathrm{C}$ sink ranging from -0.9 to $-1.4 \mathrm{Pg} \mathrm{yr}^{-1}$, which is smaller than that of the AR4 estimate of the residual terrestrial sink but within their uncertainty range $\left(-2.6 \pm 1.7 \mathrm{TgC} \mathrm{yr}^{-1}\right)$. The AR4 estimate may include nitrogen fertilization and other effects that are not in the 2 biogeochemical models. Our consolidated estimate of the net global terrestrial carbon flux (i.e. the sum of emissions and uptake, $-0.4 \mathrm{PgC} \mathrm{yr}^{-1}$ ) is also smaller than that of the 
AR4 assessment, but still just within the uncertainty range derived from a combination of inverse models and observations $\left(-1.0 \pm 0.6 \mathrm{PgC} \mathrm{yr}^{-1}\right)$.

Estimates of LULUCF emissions from the UNFCCC that are nearly global in scope are $-0.25 \mathrm{PgC} \mathrm{yr}^{-1}$. The UNFCCC guidelines suggest that this estimate should include all processes as does our consolidated estimate. However, these two estimates are not always comparable. In order to investigate the possible reasons for the large differences between the different estimates, we investigated two specific countries. For example, our consolidated estimate includes carbon fluxes in non-forested areas (e.g. USA) and the time lag in emissions (e.g. Brazil).

In the USA, the UNFCCC estimate, EMI1, only accounts for the carbon stock change for the SOC pool in forests, while the other estimates include nonforests. When the comparison is restricted to forested land, the UNFCCC re-

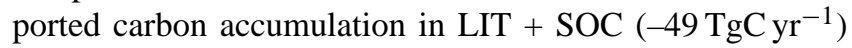
is smaller than the range of values for different models

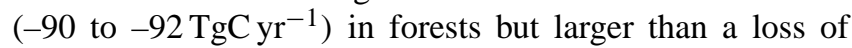
$51 \mathrm{TgC} \mathrm{yr}^{-1}$ for all land cover types in one estimate (EMI7). Only EMI2, 3 and 4 include the effects of fire suppression on LUC fluxes, but EMI1 excludes woody encroachment in nonforests. When the comparison is restricted to forested lands, the UNFCCC reported net carbon sink $\left(-0.19 \mathrm{PgC} \mathrm{yr}^{-1}\right)$ is in better agreement with EMI3 $\left(-0.23 \mathrm{PgC} \mathrm{yr}^{-1}\right)$ but larger than that in EMI4 $\left(-0.11 \mathrm{PgC} \mathrm{yr}^{-1}\right)$ which includes all land cover use types. Nevertheless, the UNFCCC estimate (EMI1) is much smaller than the sink estimated by inverse models.

Pasture and cropland conversion to forests lead to a net $\mathrm{C}$ emission from Brazil in the range -0.33 to $+0.43 \mathrm{PgC} \mathrm{yr}^{-1}$ from different estimates, compared to a source of $+0.19 \mathrm{PgC} \mathrm{yr}^{-1}$ from UNFCCC. Even the use of the same primary data set (i.e., FAO, SAGE, and HYDE) can lead to differences in the total area associated with LUC when secondary assumptions are applied to the data sets compared in this study. Differences are possibly caused by different implementations of different primary data to secondary data in the conversion of natural forests to managed lands and vice versa: the satellite based classifications used for the present-day natural vegetation cover versus classification based on ground observations, the use of fractional natural plant functional types versus a single land-use type approach, and the application of the "net" changes in LUC areas within different resolutions treated by different models. In addition, the response to climate change and fertilization in the 2 biogeochemical cycle models that we compared ranged from -122 to $-448 \mathrm{TgC} \mathrm{yr}^{-1}$, which was a significantly larger range than the range found in the USA ( -7 to $\left.-45 \mathrm{TgC}_{\mathrm{yr}}^{-1}\right)$.

Our consolidated estimate of the terrestrial carbon flux for Latin America in the $1990 \mathrm{~s}\left(-0.17 \mathrm{PgC} \mathrm{yr}^{-1}\right)$ is within the uncertainty range of inversion estimates $\left(0.43 \pm 0.86 \mathrm{PgC} \mathrm{yr}^{-1}\right)$ but results in smaller inter-annual variability in the $\mathrm{CO}_{2}$ flux than that found in estimates based on inversion (Baker et al., 2006). For Temperate North America, our consolidated estimate shows a weaker uptake than the inverse estimates. The differences between the net fluxes estimated by the emissions models and by the atmospheric inversions can be caused by large uncertainties in LIT and SOC sinks for the USA and by significant uncertainties in short-term fluxes for Latin America, as well as by different responses to LUCF and environmental changes. These differences show that significant efforts are still needed to resolve differences in LUCF emissions at the regional and country levels. Moreover, the agreement found above at the global level between inverse estimates of the net carbon fluxes and those from this bottom-up study may be due to compensations between our weak total sink in the Northern Hemisphere and smaller LUCF emissions in the Southern Hemisphere.

Acknowledgements. Support for this research was provided to A. Ito by Innovative Program of Climate Change Projection for the 21st Century (MEXT). JEP and MJP acknowledge support from the Radiation Sciences Program at NASA. Support of this research was partly provided to C. P. de Campos by the Brazilian National Counsel of Technological and Scientific Development and partially by Petrobras. We wish to thank M. Jung for coordinating this work through the MATCH project.

Edited by: F. J. Dentener

\section{References}

Achard, F., Eva, H. D., Stibig, H. J., Mayaux, P., Gallego, J., Richards, T., and Malingreau, J. P.: Determination of deforestation rates of the world's humid tropical forests, Science, 297, 999-1002, 2002.

Achard, F., Eva, H. D., Mayaux, P., Stibig, H.-J., and Belward, A.: Improved estimates of net carbon emissions from land cover change in the tropics for the 1990s, Global Biogeochem. Cy., 18, GB2008, doi:10.1029/2003GB002142, 2004.

Albani, M., Medvigy, D., Hurtt, G. C., and Moorcroft, P. R.: The contributions of land-use change, $\mathrm{CO}_{2}$ fertilization, and climate variability to the Eastern US carbon sink, Global Change Biol., 12, 2370-2390, 2006.

Amichev, B. Y. and Galbraith, J. M.: A revised methodology for estimation of forest soil carbon from spatial soils and forest inventory data sets, Environ. Manage., 33(Suppl. 1), S74-S86, 2004.

Amundson, R.: The carbon budget in soils. Annu. Rev. Earth Planet. Sci., 29, 535-562, 2001.

Asner, G. P., Knapp, D. E., Broadbent, E. N., Oliveira, P. J. C., Keller, M., and Silva, J. N.: Selective Logging in the Brazilian Amazon, Science, 310, 480-482, 2005.

Baker, D. F., Law, R. M., Gurney, K. R., et al.: TransCom 3 inversion intercomparison: Impact of transport model errors on the interannual variability of regional $\mathrm{CO}_{2}$ fluxes, 1988-2003, Global Biogeochem. Cy., 20, GB1002, doi:10.1029/2004GB002439, 2006. 
Bartholomé, E. and Belward, A. S.: GLC2000: a new approach to global land cover mapping from Earth observation data, Int. J. Remote Sens., 26, 1959-1977, 2005.

Betts, R. A., Falloon, P. D., Klein Goldewijk, K., and Ramankutty, N.: Biogeophysical effects of land use on climate: Model simulations of radiative forcing and large-scale temperature change, Agr. For. Metetorol., 142, 216-233, 2007.

Birdsey, R. A., and Heath, L. S.: Carbon changes in US forests, in: Productivity of America's Forests and Climate Change, edited by: Joyce, L. A., USDA Forest Service, Rocky Mountain Forest and Range Experiment Station, GTR-RM-271, Fort Collins, Colorado, USA, 56-70, 1995.

Birdsey, R. and Heath, L. S.: Forest inventory data, models, and assumptions for monitoring carbon flux, in: Soil Carbon Sequestration and the Greenhouse Effect, SSSA Special Publication No. 57. Soil Science Society of America, Madison, Wisconsin, USA, 125-135, 2001.

Brazil Ministry of Science and Technology: Brazil's initial National Communication to the United Nations Framework Convention on Climate Change, report, General Coordination on Global Climate Change, Brazilia, Brazil, 2004.

Brown, S. and Lugo, A. E.: Tropical secondary forests, J. Trop. Ecol., 6, 1-32, 1990.

Brown, S., Lugo, A. E., and Chapman, J.: Biomass of tropical tree plantations and its implications for the global carbon budget, Can. J. Forest Res., 16 390-16 394, 1986.

Caspersen, J. P., Pacala, S. W., Jenkins, J. C., Hurtt, G. C., Moorcroft, P. R., and Birdsey, R. A.: Contributions of land-use history to carbon accumulation in U.S. forests, Science, 290, 11481151, 2000.

Chevallier, F., Breon, F.-M., and Rayner, P. J.: Contribution of the Orbiting Carbon Observatory to the estimation of $\mathrm{CO}_{2}$ sources and sinks: Theoretical study in a variational data assimilation framework, J. Geophys. Res., 112, D09307, doi:10.1029/2006JD007375, 2007.

Cramer, W., Bondeau, A., Woodward, F. I., et al.: Global response of terrestrial ecosystem structure and function to $\mathrm{CO}_{2}$ and climate change: Results from six dynamic global vegetation models, Global Change Biol., 7, 357-373, 2001.

Davidson E. A. and Janssens, I. A.: Temperature sensitivity of soil carbon decomposition and feedbacks to climate change, Nature, 440, 165-173, 2006.

de Campos, C. P.: Historical land use change $\mathrm{CO}_{2}$ emissions from land use change to agriculture and pasture and the climate change contributions by country - the Proposal by Brazil to the Climate Convention, Ph.D. thesis, Energy Planning Program of Federal University of Rio de Janeiro, Rio de Janeiro, Brazil, 2007.

de Campos C. P., Muylaert, M. S., and Rosa, L. P.: Historical $\mathrm{CO}_{2}$ emission and concentrations due to land use change of croplands and pastures by country, Sci. Tot. Environ., 346, 149-155, 2005.

DeFries, R. S., Houghton, R. A., Hansen, M. C., et al.: Carbon emissions from tropical deforestation and regrowth based on satellite observations for the 1980s and 1990s, Proc. Natl. Acad. Sci., U.S.A., 99, 14 256-14 261, 2002.

Denman, K. L., Brasseur, G., Chidthaisong, A., et al.: Couplings between changes in the climate system and biogeochemistry, in: Climate Change 2007: The Physical Science Basis. Contribution of Working Group I to the Fourth Assessment Report of the Intergovernmental Panel on Climate Change, edited by: Solomon,
S., Qin, D., Manning, M., Chen, Z., Marquis, M., Averyt, K. B., Tignor, M., and Miller, H. L., Cambridge University Press, Cambridge, United Kingdom and New York, New York, USA, 2007.

Enting, I. G.: Inverse Problems in Atmospheric Constituent Transport, Cambridge U. Press, USA, 2002.

Eva, H. D., Belward A. S., De Miranda E., Di Bella C. M., Gond V., Huber O., Jones S., Sgrenzaroli M., and Fritz S.: A land cover map of South America, Global Change Biol., 10, 731-744, 2004.

FAO: Forest resources assessment 1990; Tropical countries, FAO, Rome. Report FP-112, Italy, 1993.

FAO: Assessing state and change in global forest cover: 2000 and beyond, Forest Resources Assessment Programme, Working Paper 31, FAO, Rome, Italy, 2000.

FAO: Global Forest Resources Assessment 2005, FAO Forestry Paper 147, FAO, Rome Italy, 2006.

FAOSTAT: Statistical Database of the United Nations Food and Agricultural Organization, http://apps.fao.org/, access: February 2004.

FAOSTAT: Statistical Database of the United Nations Food and Agricultural Organization, http://apps.fao.org/, access: October 2005.

Farquhar, G. D., Von Caemmerer, S., and Berry, J. A.: A biochemical model of photosynthetic $\mathrm{CO}_{2}$ assimilation in leaves of $\mathrm{C}_{3}$ species, Planta, 149, 78-90, 1980.

Fearnside, P. M.: Global warming and tropical land-use change: Greenhouse gas emissions from biomass burning, decomposition and soils in forest conversion, shifting cultivation and secondary vegetation, Clim. Change, 46, 115-158, 2000.

Friedlingstein, P., Cox, P., Betts, R., et al.: Climate-carbon cycle feedback analysis: Results from the C4MIP model intercomparison, J. Clim., 19, 3337-3353, 2006.

Gerbig, C., Lin, J. C., Wofsy, S. C., Daube, B. C., Andrews, A. E., Stephens, B. B., Bakwin, P. S., and Grainger, C. A.: Toward constraining regional-scale fluxes of $\mathrm{CO}_{2}$ with atmospheric observations over a continent: 2 . Analysis of COBRA data using a receptor-oriented framework, J. Geophys. Res., 108, 4757, doi:10.1029/2003JD003770, 2003.

Giardina, C. P. and Ryan, M. G.: Evidences that decomposition rates of organic carbon in mineral soil do not vary with temperature, Nature, 404, 858-861, 2000.

Gruber, N. and Galloway, J. N.: An Earth-system perspective of the global nitrogen cycle, Nature, 451, 293-296, 2008

Gullison, R. E., Frumhoff, P. C., Canadell, J. G., et al.:, Tropical forests and climate policy, Science, 316, 985-986, 2007.

Guo Y. Y., Gong, P., Amundson, R., and Yu, Q.: Analysis of factors controlling soil carbon in the conterminous United States, Soil Sci. Soc. Amer. J., 70, 601-612, 2006.

Gurney, K. R., Law, R. M., Denning, A. S., et al.: Towards robust regional estimates of $\mathrm{CO}_{2}$ sources and sinks using atmospheric transport models, Nature, 415, 626-630, 2002.

Gurney, K. R., Law, R. M., Denning, A. S., et al.: Transcom 3 inversion intercomparison: Model mean results for the estimation of seasonal carbon sources and sinks, Global Biogeochem. Cy., 18, GB1010, doi:10.1029/2003GB002111, 2004.

Harmon, M. E. and Hua, C.: Coarse woody debris dynamics in two old-growth ecosystems, BioScience, 41, 604- 610, 1991. 
Harmon, M. E., Krankina, O. N., Yatskov, M., and Matthews, E.: Predicting broad-scale carbon stores of woody detritus from plotlevel data, in: Assessment Methods for Soil Carbon, edited by: Lal, R., Kimble, J. M., Follett, R. F., and Stewart, B. A., Lewis Publishers, 533-552, Boca Raton, Fla, USA, 2001.

Heath, L. S., Smith, J. E., and Birdsey, R. A.: The potential of US forest soils to sequester carbon and mitigate the greenhouse effect carbon trends in U. S. Forestlands, in: A Context for the Role of Soils in Forest Carbon Sequestration, edited by: Kimble, J. M., Heath, L. S., Birdsey, R. A., and Lal, R., Lewis Publishers, 383-394, Boca Raton, FL, USA, 2003.

Heimann, M. and Reichstein, M.: Terrestrial ecosystem carbon dynamics and climate feedbacks, Nature, 451, 289-292, 2008

Houghton, R. A.: Revised estimates of the annual net flux of carbon to the atmosphere from changes in land use 1850-2000, Tellus, Ser. B, 55, 378- 390, 2003.

Houghton, R. A. and Hackler, J. L.: Emissions of carbon from forestry and land-use change in tropical Asia, Global Change Biol., 5, 481-492, 1999.

Houghton, R. A. and Hackler, J. L.: Sources and sinks of carbon from land-use change in China, Global Biogeochem. Cy., 17, 1034, doi:10.1029/2002GB001970, 2003.

Houghton, R. A., Hackler, J. L., and Lawrence, K. T.: The US carbon budget: Contributions from land-use change, Science 285, 574-578, 1999.

Houghton, R. A. and Ramakrishna, K.: A review of national emissions inventories from select non-Annex I countries: Implications for counting sources and sinks of carbon, Ann. Rev. Energy Environ., 24, 571-605, 1999.

Houghton, R. A., Hobbie, J. E., Melillo, J. M., Moore, B., Peterson, B. J., Shaver, G. R., and Woodwell, G. M.: Changes in the carbon content of terrestrial biota and soils between 1860 and 1980: A net release of $\mathrm{CO}_{2}$ to the atmosphere. Ecol. Monogr. 53, 235262, 1983.

Houghton R. A., Skole, D. L., Nobre, C. A., Hackler, J. L., Lawrence K. T., and Chomentowski, W H.: Annual fluxes of carbon from deforestation and regrowth in the Brazilian Amazon, Nature, 403, 301-304, 2000.

House, J. I., Prentice, I. C., Ramankutty, N., Houghton, R. A., and Heimann, M.: Reconciling apparent inconsistencies in estimates of terrestrial $\mathrm{CO}_{2}$ sources and sinks, Tellus, Ser. B, 55, 345-363, 2003.

Hurtt, G. C., Pacala, S. W., Moorcroft, P. R., Caspersen, J., Shevliakova, E., Houghton, R. A., and Moore III, B.: Projecting the future of the U.S. carbon sink, Proc. Natl. Acad. Sci., USA, 99, 1389-1394, 2002.

Hurtt G. C., Frolking, S., Fearon, M. G., Moore, B., Shevliakova, E., Malyshev, S., Pacala, S. W., and Houghton, R. A.: The underpinnings of land-use history: Three centuries of global gridded land-use transitions, wood-harvest activity, and resulting secondary lands, Global Change Biol., 12, 1208-1229, 2006.

IPCC: Revised 1996 IPCC Guidelines for National Greenhouse Gas Inventories. IPCC/OECD/IEA, Paris, France, 1997.

IPCC: Land Use, Land-Use Change and Forestry: A special report of Working Group III of the Intergovernmental Panel on Climate Change, edited by: Watson, R. T., Noble, I. R., Bolin, B., Ravindranath, N. H., Verardo, D. J., and Dokken D. J., Cambridge University Press, Cambridge, UK, 2000.
IPCC: Good Practice Guidance for Land Use, Land-Use Change, and Forestry. The Intergovernmental Panel on Climate Change, National Greenhouse Gas Inventories Programme, edited by: Penman, J., Gytarsky, M., Hiraishi, T., et al., http://www. ipcc-nggip.iges.or.jp/public/gpglulucf/gpglulucf.htm, 2003.

IPCC: 2006 IPCC guidelines for National Greenhouse Gas Inventories, Agriculture, Forestry and Other Land Use, edited by: Eggleston, S., Buendia, L., Miwa, K., Ngara, T., and Tanabe, K., http://www.ipcc-nggip.iges.or.jp/public/2006gl/vol4.html, 2006.

Ito, A., Ito, A., and Akimoto, H.: Seasonal and interannual variations in $\mathrm{CO}$ and $\mathrm{BC}$ emissions from open biomass burning in Southern Africa during 1998-2005, Global Biogeochem. Cy., 21, GB2011, doi:10.1029/2006GB002848, 2007a.

Ito, A., Sudo, K., Akimoto, H., Sillman, S., and Penner, J. E.: Global modeling analysis of tropospheric ozone and its radiative forcing from biomass burning emissions in the twentieth century, J. Geophys. Res., 112, D24307, doi:10.1029/2007JD008745, $2007 b$.

Ito, A. H., Muraoka, H., Koizumi, H., Saigusa, N., Murayama, S., and Yamamoto, S.: Seasonal variation in leaf properties and ecosystem carbon budget in a cool-temperate deciduous broadleaved forest: Simulation analysis at Takayama site, Japan, Ecol. Res., 21, 137-149, 2006.

Ito, A. H. and Oikawa, T.: A simulation model of the carbon cycle in land ecosystems (Sim-CYCLE): A description based on drymatter production theory and plot-scale validation Source, Ecol. Model, 151, 143-176, 2002.

Jacobson, A. R., Mikaloff Fletcher, S. E., Gruber, N., Sarmiento, J. L., and Gloor, M.: A joint atmosphere-ocean inversion for surface fluxes of carbon dioxide: 1. Methods and global-scale fluxes, Global Biogeochem. Cy., 21, GB1019, doi:10.1029/2005GB002556, 2007.

Jain, A. K., Tao, Z., Yang, X., and Gillespie, C.: Estimates of global biomass burning emissions for reactive greenhouse gases (CO, NMHCs, and $\mathrm{NO}_{x}$ ) and $\mathrm{CO}_{2}$, J. Geophys. Res., 111, D06304, doi:10.1029/2005JD006237, 2006.

Jain, A. K. and Yang, X.: Modeling the effects of two different land cover change data sets on the carbon stocks of plants and soils in concert with $\mathrm{CO}_{2}$ and climate change, Global Biogeochem. Cy., 19, GB2015, doi:10.1029/2004GB002349, 2005.

Janzen, H.: Carbon cycling in earth systems a soil science perspective. Agr. Ecosyst. Environ., 104, 399-417, 2004.

Jenkinson, D. S.: The turnover of organic carbon and nitrogen in soil, Philos. Trans. R. Soc. London, Ser. B, 329, 361-368, 1990.

Jones C., McConnell, C., Coleman, K., Cox, P., Falloon, P., Jenkinson, D., Powlson, D.: Global climate change and soil carbon stocks; predictions from two contrasting models for the turnover of organic carbon in soil, Global Change Biol., 11, 154-166, 2005.

Kawamiya, M., Yoshikawa, C., Sato, H., Sudo, K., Watanabe, S., and Matsuno, T.: Development of an integrated earth system model on the Earth Simulator, J. Earth Simurator, 4, 18-30, 2005.

Krankina, O. N., Harmon, M. E., Kukuev, Y. A., et al.: Coarse woody debris in forest regions of Russia, Can. J. For. Res., 32, 768-778, 2002.

Klein Goldewijk, K.: Estimating global land use change over the past 300 years: The HYDE database, Global Biogeochem. Cy., 15, 417-433, 2001. 
Klein Goldewijk, K. and Ramankutty, N.: Land cover change over the last three centuries due to human activities: The availability of new global data sets, GeoJournal, 61, 335-344, 2004.

Knorr W., Prentice, I. C., House, J. I., and Holland, E. A.: Longterm sensitivity of soil carbon turnover to warming, Nature, 433, 298-301, 2005.

Luo, Y., Wan, S., Hui, D., and Wallace, L. L.: Acclimatization of soil respiration to warming in a tall grass prairie, Nature, 413, 622-625, 2001.

Matthews, E.: Global vegetation and land use: New high-resolution data bases for climate studies, J. Clim. Appl. Meteorol., 22, 474487, 1983.

Matthews, E.: Global litter production, pools, and turnover times: Estimates from measurement data and regression models, J. Geophys. Res., 102, 18 771-18 800, 1997.

McGuire, A. D., Sitch, S., Clein, J. S., et al.: Carbon balance of the terrestrial biosphere in the twentieth century: Analyses of $\mathrm{CO}_{2}$, climate and land use effects with four process based ecosystem models, Global Biogeochem. Cy. 15, 183-206, 2001.

Nepstad, D. C, Verissimo, A., Alencar, A., Nobre, C., Lima, E., Lefebvre, P., Schlesinger, P., Potter, C., Moutinho, P., Mendoza, E., Cochrane, M., and Brooks, V.: Large-scale impoverishment of Amazonian forests by logging and fire, Nature, 398, 505-508, 1999.

Norby, R. J., DeLucia, E. H., Gielen, B., et al.: Forest response to elevated $\mathrm{CO}_{2}$ is conserved across a broad range of productivity, Proc. Natl. Acad. Sci., USA, 102, 18 052-18 056, 2005.

Oliveira, P. J. C., Asner, G. P., Knapp, D. E., Almeyda, A., GalvánGildemeister, R., Keene, S., Raybin, R. F., and Smith, R. C.: Land-use allocation protects the Peruvian Amazon, Science, 31, 1233-1236, 2007.

Olivier, J. G. J., and Berdowski, J. J. M.:Global emissions sources and sinks, in: The Climate System, Berdowski, J., Guicherit, R., and Heij, B. J. (Eds.), A. A. Balkema Publishers/Swets \& Zeitlinger Publishers, Lisse, The Netherlands, 33-78, 2001.

Pak, B. C. and Prather, M. J.: $\mathrm{CO}_{2}$ source inversions using satellite observations of the upper troposphere, Geophys. Res. Lett., 28, 4571-4574, 2001.

Pacala, S. W., Hurtt, G. C., Baker, D., et al.: Consistent landand atmosphere-based US carbon sink estimates, Science, 292, 2316-2320, 2001.

Pastor, J. and Post, W. M.: Development of a linked forest productivity-soil process model, Tech. Rep. ORNL/TM-9519, Oak Ridge Natl. Lab., Oak Ridge, Tenn, USA, 1985.

Patra, P. K., Gurney, K. R., Denning, A. S., et al.: Sensitivity of inverse estimation of annual mean $\mathrm{CO}_{2}$ sources and sinks to oceanonly sites versus all-sites observational networks, Geophys. Res. Lett., 33, L05814, doi:10.1029/2005GL025403, 2006.

Pietsch, S. A. and Hasenauer, H.: Evaluating the self-initialization procedure for large-scale ecosystem models, Global Change Biol., 12, 1658-1669, 2006.

Ramankutty, N. and Foley, J.: Characterizing patterns of global land use: An analysis of global croplands data, Global Biogeochem. Cy., 12, 667-685, 1998.

Ramankutty, N. and Foley, J. A.: Estimating historical changes in global land cover: Croplands from 1700 to 1992, Global Biogeochem. Cy., 13, 997-1027, 1999.
Ramankutty. N., Gibbs, H. K., Achard, F., DeFries, R., Foley, J. A., and Houghton, R. A.: Challenges to estimating carbon emissions from tropical deforestation, Global Change Biol., 13, 5166, 2007.

Reich, P. B., Hobbie, S. E., Lee, T., et al.: Nitrogen limitation constrains sustainability of ecosystem response to $\mathrm{CO}_{2}$, Nature, 440 , 922-925, 2006.

Sarrat, C., Noilhan, J., Lacarrèreet P., et al.: Atmospheric $\mathrm{CO}_{2}$ modeling at the regional scale: Application to the CarboEurope Regional Experiment, J. Geophys. Res., 112, D12105, doi:10.1029/2006JD008107, 2007.

Schulze, E.-D., Mollicone D., Achard F., Matteucci G., Federici S., Eva H. D., and Valentini R.: Making deforestation pay under the Kyoto protocol?, Science, 299, 1669, 2003.

Smith, J. E., Heath, L. S., and Woodbury, P. B.: How to estimate forest carbon for large areas from inventory data, J. For., 102, 25-31, 2004a.

Smith, W. B., Miles, P. D., Vissage, J. S., and Pugh, S. A.: Forest Resources of the United States, 2002. General Technical Report NC-241, US Department of Agriculture Forest Service, North Central Research Station, St. Paul, MN, USA, 2004b.

Stephens, B. B., Gurney, K. R., Tans, P. P., et al.: Weak northern and strong tropical land carbon uptake from vertical profiles of atmospheric $\mathrm{CO}_{2}$, Science, 316, 1732-1735, 2007.Sitch, S., Cox, P. M., Collins, W. J., and Huntingford, C.: Indirect radiative forcing of climate change through ozone effects on the land-carbon sink, Nature, 448, 791-794, 2007.

Takata, K., Emori, S., and Watanabe, T.: Development of the minimal advanced of the surface interaction and runoff, Global Planetary Change, 38, 209-222, 2003.

Thornthwaite, C. W. and Mather, J. R.: Instructions and tables for computing potential evapotranspiration and the water balance, Publ. Climatol., 10, 183-311, 1957.

Thornton, P. E., Lamarque, J.-F., Rosenbloom, N. A., and Mahowald, N. M.: Influence of carbon-nitrogen cycle coupling on land model response to $\mathrm{CO}_{2}$ fertilization and climate variability, Global Biogeochem. Cy., 21, GB4018, doi:10.1029/2006GB002868, 2007.

US Environmental Protection Agency: Inventory of U.S. greenhouse gas emissions and sinks: 1990-2005, report, Off. of Atmos. Programs, Washington, D. C., USA, 2007.

USDA: State Soil Geographic (STATSGO) Data Base Data use information. Miscellaneous Publication Number 1492, National Soil Survey Center, Natural Resources Conservation Service, US Department of Agriculture, Fort Worth, TX, USA, 1991.

UNFCCC (United Nations Framework Convention on Climate Change): Sixth compilation and synthesis of initial national communications from Parties not included in Annex I to the Convention. Note by the Secretariat, Subsidiary Body for Implementation, FCCC/SBI/2005/18, Montreal, 2005.

UNFCCC (United Nations Framework Convention on Climate Change): National greenhouse gas inventory data for the period 1990-2005. Note by the Secretariat, Subsidiary Body for Implementation, FCCC/SBI/2007/30, Bali, 2007.

van Aardenne, J. A., Dentener, F. J., Olivier, J. G. J., Klein Goldewijk, C. G. M., and Lelieveld, J: A $1^{\circ} \times 1^{\circ}$ resolution data set of historical anthropogenic trace gas emissions for the period 18901990, Global Biogeochem. Cy., 15, 909-928, 2001. 
van der Werf, G. R., Randerson, J. T., Collatz, G. J., Giglio, L., Kasibhatla, P. S., Arellano, Jr. A. F., Olsen, S. C., and Kasischke, E. S.: Continental-scale partitioning of fire emissions during the 1997 to $2001 \mathrm{El} \mathrm{Niño/La} \mathrm{Niña} \mathrm{period,} \mathrm{Science,} \mathrm{303,} \mathrm{73-}$ 76, 2004.

Wang, A., Price, D. T., and Arora, V.: Estimating changes in global vegetation cover (1850-2100) for use in climate models, Global Biogeochem. Cy., 20, GB3028, doi:10.1029/2005GB002514, 2006.
Wang, J.-W., Denning, A. S., Lu, L., Baker, I. T., Corbin, K. D., and Davis, K. J.: Observations and simulations of synoptic, regional, and local variations in atmospheric $\mathrm{CO}_{2}$, J. Geophys. Res., 112, D04108, doi:10.1029/2006JD007410, 2007.

Woodbury, P. B., Heath, L. S., and Smith, J. E.: Effects of land use change on soil carbon cycling in the conterminous United States from 1900 to 2050, Global Biogeochem. Cy., 21, GB3006, doi:10.1029/2007GB002950, 2007. 